
\title{
Research Suare \\ Small Business and the COVID-19 Pandemic: The Role of Work from Home
}

\section{Ting Zhang ( $\nabla$ tzhang@ubalt.edu )}

University of Baltimore

Dan Gerlowski

University of Baltimore

Zoltan Acs

George Mason University

\section{Research Article}

Keywords: Work from home, COVID-19, Small Business, Stay-at-home Order JEL: O33, L25, L16, M54,

Posted Date: September 29th, 2020

DOI: https://doi.org/10.21203/rs.3.rs-83264/v1

License: (1) This work is licensed under a Creative Commons Attribution 4.0 International License. Read Full License 


\title{
Small Business and the COVID-19 Pandemic: \\ The Role of Work from Home
}

Ting Zhang, corresponding author, tzhang@ubalt.edu,

Associate Professor, Merrick School of Business,

Associate Director, Jacob France Institute

University of Baltimore, 1420 N. Charles Street, Baltimore, MD 21201

\author{
Dan Gerlowski, \\ Professor, Merrick School of Business, \\ University of Baltimore, 1420 N. Charles Street, Baltimore, MD 21201
}

and

Zoltan Acs,

Director, Center for Entrepreneurship and Public Policy;

University Professor, Schar School of Policy and Government,

George Mason University, 3351 Fairfax Dr., MS 3B1, Arlington, Virginia 22201

\begin{abstract}
Work from home (WFH) becomes the new norm in the COVID-19 pandemic. Whether the WFH norm will fade or accelerate after the stay-at-home mandate ends is unknown. The study builds a theoretical framework based on utility maximization theory subject to a "contagion" agglomeration parameter and argues that WFH is a rational choice for small businesses. We compiled an up-to-date real-time daily and weekly multifaceted data set tracking WFH propensity from March 20 through July 28. Our empirical analysis estimated a variety of fixed-effects panel data models, populationaveraged generalized linear panel-data models with the generalized estimating equation (GEE) approach, and two-level mixed-effects panel-data models. After controlling for the local pandemic, economic, and demographic factors, we find
\end{abstract}


that, (1) after the stay-at-home order ended, WFH rate got higher; (2) small businesses in states with higher WFH rate are more likely to have higher increases in operating revenue, better cash flow and lower chances of temporary closure. Our robust empirics confirm our theory and hypotheses and demonstrate WFH as a potential force that expedited the "creative destruction" into a new efficient work paradigm.

\section{Keyword}

Work from home, COVID-19, Small Business, Stay-at-home Order

JEL: O33, L25, L16, M54, 


\section{Small Business and the COVID-19 Pandemic:}

\section{The Role of Work from Home}

\section{Introduction}

One disruption that the COVID crisis brought to our economy is working from home (WFH). Dingel \& Neiman (2020) found that $37 \%$ of jobs in the United States can be performed entirely at home, with variation across cities and industries. Bartik, et al. (2020b) report that $45 \%$ of firms having at least some workers switch to teleworking during the COVID-19 pandemic and over $1 / 3$ of those firms believe that WFH will remain more common at their companies after the COVID-19 crisis ends. Gallup Panel (2020) revealed that the percentage for Americans WFH doubled to over 60\% between midMarch and early April 2020 and 59\% U.S. workers who have been teleworking during the pandemic would prefer to continue WFH as much as possible, once public health restrictions are lifted, while only $41 \%$ would prefer to return to their workplace to work (Breman 2020).

Will this COVID-induced WFH disruption emerge into a Schumpeterian (1934) "creative destruction" that help businesses grow better in the long run and will small businesses (with less than 500 employees and receipts of at least $\$ 1,000$ ) ride this WFH wave well? While small businesses employ almost 50\% of American workers (Bartik, et al. 2020a), in economic crisis small businesses are vulnerable (Kolasa et al. 2010; Kennickell et al. 2017) and disproportionately negatively affected (Bartz \& Winkler 2016). While a rising number of businesses adopt WFH and while prior literature discussed separately on WFH and on crisis impact on small businesses, whether WFH helps mitigate the crisis shock on small businesses is unknown.

This paper therefore focuses on examining (1) whether WFH rates continue to rise after singling out the pandemic severity and related stay-at-home mandate, and (2) how WFH helps small businesses do better in the pandemic. The exogenous pandemic shock could have expedited the WFH norm as the new Schumpeterian (1934) "creative destruction": a norm that we were technically ready but hesitant to adopt. The future path of WFH will impact workplaces, life styles, and urban structure and planning.

The study builds a theoretical framework based on utility maximization theory subject to business costs, working hours, wages, and a contagion agglomeration parameter (Krugman 1996; Glaeser 1999), demonstrating conditions when 
WFH is a rational choice for businesses. Then, we compiled an up-to-date real-time daily and weekly multifaceted data set tracking WFH propensity from March 20 through July 28. Relying on our theory and real-time data, our empirical analysis estimated a variety of fixed-effects panel data models, population-averaged generalized linear panel-data models with the generalized estimating equation (GEE) approach, and two-level mixed-effects panel-data models.

The next section focuses on our theoretical framework, followed by our two research hypotheses. Then in the methodology section, we describe our data and present our empirical findings with robustness check After controlling for the local pandemic, economic, and demographic factors, we find (1) after the stay-at-home order (SHO) ended, WFH rates got higher; (2) small businesses in states with higher WFH rates are more likely to have an increase in operating revenue, a better cash flow situation, fewer temporary closures and fewer disruptions of supply chain.

\section{Theoretical Framework}

Our theoretical framework is cast in a cost benefit framework where workers and firms seek to be rational maximizing entities in a constrained environment comparing home and office workplaces. The four key factors of production for a firm include capital, labor, land, and technology and entrepreneurship (Bade and Parkin, 2018). Under certain technology conditions (X), it is business owners', or top managers', entrepreneurship that determines whether working in traditional brick-\&-mortar offices or WFH. Based on the utility maximization theory, a rational choice is a choice that maximize one's utility. From the labor demand perspective, hiring decisions are based on the revenue and cost a marginal employee would bring.

Employers choose WFH versus brick-\&-mortar office if WFH $(H)$ brings more marginal net benefit than work in the traditional offices $(O)$. Workers are endowed with certain skills and abilities $(\mathrm{S})$ which are dependent on the level and use of technology available to the worker (X). Better technology will increase S and hence worker marginal productivity. Facing the pandemic, workers' working hours $(\mathrm{T})$ is often affected by the pandemic conditions (P), no matter WFH or working in traditional offices. For employers, they hire employees based on employees' skills, $\mathrm{S}(\mathrm{X})$, and potential working hours, $\mathrm{T}(\mathrm{P})$, because $\mathrm{S}(\mathrm{X})$ and $\mathrm{T}(\mathrm{P})$ jointly determine potential revenue. Employers' cost spread to each employee include employees' wage $(W)$, capital or equipment, office supply and utility costs $(\mathrm{K})$, and land cost (L). In the traditional office settings, the marginal revenue of workers also benefits from an agglomeration parameter (A) (Krugman 1996; Glaeser 1999) with networking and knowledge spillovers (Saxenian 1994). In the pandemic, the location 
based agglomeration effect is constrained also by the pandemic conditions (P) with social distancing needs. Therefore, employers would choose WFH versus working in traditional offices if the marginal revenue per unit of marginal costs of WFH is larger:

$$
\frac{S(X)^{H} * T(P)^{H}}{W^{H} * K^{H} * L^{H}} \geq A(P) * \frac{S(X)^{O} * T(P)^{O}}{W^{O} * K^{O} * L^{O}}
$$

(1) can be further transformed into

$$
\frac{S(X)^{H}}{S(X)^{O}} * \frac{T(P)^{H}}{T(P)^{O}} * \frac{W^{O}}{W^{H}} * \frac{K^{O}}{K^{H}} * \frac{L^{O}}{L^{H}} * \frac{1}{A(P)} \geq 1
$$

For employers, the labor search pool is enlarged beyond the local scope, resulting the employee skills out of location-unbounded web search, $S^{H}$, potentially better matched with the job than that out of local search only; for the same job, WFH would potentially require more technology savviness. Therefore, $S(X)^{H}>S(X)^{O}$, i.e., $\frac{S(X)^{H}}{S(X)^{O}}>1$.

As for hours committed to work, many WFH workers feel the need to reciprocate the privilege of WFH with flexibility, autonomy, and saved commuting time by working longer hours and/or harder work (Gajendran \& Harrison 2007), mirrored with empirical evidence on longer hours for WFH (Kelliher \& Anderson 2010; Mariani 2000) or "hard to plug off work" in the survey (Buffer 2019). We therefore believe WFH workers work for longer hours than workers in traditional offices for a work day, i.e., $\frac{T^{H}}{T^{O}}>1$. In the pandemic, working hours in traditional office could be even shorter to limit social distancing, i.e., $\frac{T(P)^{H}}{T(P)^{O}}>1$.

With a wider labor pool to pick from, employers could potentially push the wage rate from WFH labor lower. As Mas \& Pallais (2017) found, an average worker is willing to give up 8 percent of wages for WFH. This percentage could be much higher facing a pandemic health threat and high unemployment. Firms may regard WFH as a means to increase motivation and commitment (Caillier 2012; Eaton 2003). Bourdeau et al (2019) identify a flexibility stigma associated with WFH as a characteristic violating the work devotion schema that calls for intensive allegiance, dedication, and undivided attention to the workplace, which could push WFH wages lower. Therefore, wage rate for workers working in traditional offices, $W^{O}$, could be higher than wage rate for WFH employees for the same type of work, $W^{H}$. This means $\frac{W^{O}}{W^{H}}>1$ 
For traditional office settings, business owners are obligated for capital or Administrative \& General (A\&G) costs like utilities, equipment, office furniture, supplies, and an office manager's salary to handle those administrative issues. In contrast, the home office setup cost for WFH case is often lower for employers: some employers might reimburse some home office supply and equipment costs and employers might need to pay for the technology to facilitate WFH, but typically not utility costs (e.g., electricity, gas, internet, telephone cost, insurance, etc.). For most small businesses, the potentially saved office costs could be even more important and the technology requirement for WFH might not have to be sophisticated or expensive with current advances in technology. Therefore, those office costs for workers working in the traditional office setting, $K^{O}$, is often larger than that for home offices for WFH, $K^{H}$, i.e. $\frac{K^{O}}{K^{H}}>1$. However, the concerns about the ability of employers to manage WFH workers (Coenen and Kok 2014) may result in some management cost, or costs of organizational change and technological investments (see Aguilera, et al. 2016) which could offset the WFH capital cost advantage. However, in the COVID pandemic, the social distancing requirements (such us keeping space from each other for at least 6 feet), the cost for Personal Protective Equipment, makes the $K^{O}$ larger, i.e., $\frac{K^{O}}{K^{H}}>1$. From the employer perspective, WFH could become a more effective and cheaper way to achieve social distancing, reduce COVID spread, and lower the cost of losing key employees.

For traditional office settings, business owners are obligated for continuous, often monthly, land costs (L), either rent or mortgage (and tax) and insurance of the offices. For small businesses, this land costs are often a major operating costs. In contrast, the home office land cost for the WFH case is often not considered and not reimbursed by the employers. Therefore $L^{H}$ is basically close to 0, except for essential offices. Matthews \& Williams (2005) noted that WFH allowed companies to make considerable savings through lower real estate costs and productivity gains. Therefore, employers' land cost for workers working in the traditional office setting, $L^{O}$, is considerably larger than the almost 0 home offices land cost for WFH, $L^{H}$, i.e. $\frac{L^{O}}{L^{H}} \rightarrow+\infty$. With a close to 0 denominator, $\frac{L^{O}}{L^{H}}$ is reaching positive infinity.

Given the benefit of agglomeration, $A>1$, for rational employers not to choose WFH versus from traditional offices in Inequation (1), $A$ has to be a positive infinity to make $\frac{1}{A}$ off-set the joint effect from all the other vectors that is a product of a positive infinity vector $\left(\frac{L^{O}}{L^{H}}\right)$ and other vectors that are larger than 1 (i.e., $\frac{S(X)^{H}}{S(X)^{O}}, \frac{W^{O}}{W^{H}}, \frac{K^{O}}{K^{H}}$, and $\left.\frac{T(P)^{H}}{T(P)^{O}}\right)$. Although A might enhance work efficiency to some extent, $A$ cannot enhance work efficiency by positive infinity folds. Plus, with the growing technology conditions $(\mathrm{X})$, the benefits of agglomeration $(\mathrm{A}>1)$ may be 
counter-balanced by the impact of technology and the likelihood of contagion for WFH workers as well, with even additional benefits such as recorded sessions, meeting transcripts, saved whiteboard images for needed review. Therefore, the probability for the agglomeration effect $A$ to be larger than $\frac{S(X)^{H}}{S(X)^{O}} * \frac{W^{O}}{W^{H}} * \frac{K^{O}}{K^{H}} * \frac{T(P)^{H}}{T(P)^{O}} * \frac{L^{O}}{L^{H}}$ is impossible. As a result, a rational employer would most likely choose WFH over traditional office work. In the pandemic, the agglomeration effect A is further compromised by social distancing needs and therefore $\mathrm{A}(\mathrm{P})$ is even smaller.

Currently WFH still face various barriers. Golden and Eddleston (2020) find empirical support in survey based research for some negative outcomes in promotions, raises, and career success for those pursuing flexible work arrangements including WFH. Firms that have not adopted WFH are likely to doubt productivity of WFH workers (see Aguilera, et al. 2016), though WFH were also found to be more productive than traditional office work (SHRM 2018) due to reasons such as less absenteeism. Any Schumpeterian "creative destruction" took a painful path to "disrupt" first before a newer and more productive or economically rational approach finally becomes a norm.

\section{Hypotheses}

When COVID-19 started to spread across the US, WFH started to dominate. This was pushed by the health concerns to limit the virus spread and correspondingly by the government SHO mandate. Although many businesses remained closed after the SHO was lifted, others reopened to partial or full business. One can easily argue that WFH would dramatically drop back to where it was before the COVID-19 started after the virus is contained or would be at least less popular after the SHO ends. However, based on our theoretical framework, since WFH seems a rational choice for businesses, we believe WFH would be gaining popularity and should not sharply drop because of the end of SHO. In addition, out of this COVID pandemic, firms have now paid the fixed costs of learning how to make remote working functional (Bartik, et al., 2020b) and are more aware of the potential of WFH. Many firms did not adopt WFH before the pandemic either because of ignorance or coordination issues (Bartik, et al. 2020b). After this unexpected natural experiment and learning by doing experience of WFH in the pandemic, the paid fixed costs to facilitate WFH, the related work coordination, and the enhanced awareness of the WFH advantages may make WFH a real optimal for many businesses. Although some companies may return to traditional office setting, many firms may continue adopting WFH after the SHO ended or even after the pandemic is over. Both surveys in Bartik, et al. (2020b) show that 40\% of both large and small firms expect that at least $40 \%$ of their workers who switched to remote work during the crisis will work 
remotely after the crisis. Although the pandemic is unpleasant, it could have expedited our economy to utilize the new technological frontier better. We therefore hypothesize, the popularity of WFH would continue, ceteris paribus:

Hypothesis 1: After controlling for the local pandemic, economic, and demographic conditions, the WFH rate would not sharply drop after the SHO ended.

Although adopting WFH practices often requires organizational changes, such as surveillance and control or management of the psycho-sociological distance from the work environment (Belanger 1999; Taskin and Devos 2005; Wilton et al., 2011), WFH could save turnover cost from businesses because WFH increases employee well-being by reducing travel-related fatigue, providing a less stressful work environment (Ravi S. \& David A. 2007; Redman et al., 2009) and a better balance between work and family life (Wheatley 2012), reducing the costs of commuting, pollution and urban congestion (Helminen and Ristimäki 2007; Mokhtarian et al. 2004), and even elevating productivity (Belanger 1999; SHRM 2018). Bailey and Kurland (2002) declare that in almost all empirical articles they examined, WFH was associated with higher productivity because of less absenteeism (Kitou and Horvath 2008).

A study by Belzunegui-Eraso and Erro-Garcés (2020) showed that WFH is being used by many companies to keep productivity up during the crisis, and that adopting WFH contributes to a reduced hit to GDP as a result of the crisis. Bartik, et al. (2020b) also noted that industries that are better suited to remote work also seemed to experience less productivity loss when switching to remote work. We therefore believe WFH can mitigate the negative economic impact from the COVID shock and help small businesses do better in the pandemic.

In a pandemic, it is often expected that a small business might temporarily close. Bartik, et al. (2020a) reported $43 \%$ of small businesses they surveyed did temporarily close and cited fragile financing with less than one month of cash on hand. On the other hand, Bartz \& Winkler (2016), using German data for the 2009 crisis, identified relative growth advantages among small businesses due to flexibility. Temporary closures have important implications for the US workforce. The cash flow position often signals time-to-failure for small businesses. In addition, disruptions in the supplychain exhibit challenges that other businesses are facing and have implications about the economy as a whole (Buffington, et al. 2020). Whether the operating revenue is increased is a direct indicator for business performance. Considering the potential impacts from financial assistance from the Paycheck Protection Program (PPP), we add those controls as well as aforementioned controls. Therefore we hypothesize: 
Hypothesis 2: A higher (versus lower) WFH rate helps small businesses perform better in the pandemic with a lower probability of temporary closures, with more operating revenues, and with better cash flow positions, controlling for local pandemic, economic, demographic, and financial assistance program conditions.

\section{Methodology}

Our analysis demonstrates robustness across various specifications in three types of models: the fixed-effect cross-section time-series panel-data model, population-averaged generalized linear panel-data models with the generalized estimating equation (GEE) approach, and two-level mixed-effects panel-data model: Most of the independent variables adopted oneperiod lag to capture a sequential effect. In this section, we first explain our empirical models and variables. Then we present our data sources and variables measures.

\section{Empirical Models and Variables}

To test Hypothesis 1, we modeled the sensitivity of the end of SHO on WFH, controlling for local demographic, economic, and pandemic conditions. Our data is cross-sectional time-series data, assuming correlations over time for each state (or Washington D.C. (DC)) and independence between 50 states (and DC) in the United States. We started with the fixed-effect panel data modeling, fixed at the individual states:

$$
\begin{aligned}
& \text { WFH }_{j t}=\beta_{0}+\beta_{1} \operatorname{AfterSHO}_{j t}+\gamma_{i} \sum_{i=1}^{4} \operatorname{COVID}_{j(t-1)}+\eta_{i} \sum_{i=1}^{3} \operatorname{ECON}_{j(t-1)} \\
& +\theta_{i} \sum_{i=1}^{4} \operatorname{Demographics}_{j(t-1)}+v_{j}+\varepsilon_{j t} .
\end{aligned}
$$

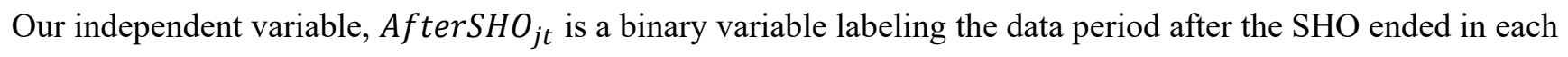
state $j$ and time period $t$; based on our theory and hypothesis, we expect $A$ fterSHO$O_{j t}$ to show a positive effect on WFH rates. COVID $_{j t}$ includes a set of four variables measuring the COVID pandemic severity. $E C O N_{j t}$ captures three local macroeconomic condition measures. Demographics ${ }_{j t}$ incorporates four demographic attributes. $v_{j}$ is the state-specific error term; it differs between states, but for any particular state, its value is constant. $\varepsilon_{j t}$ is the idiosyncratic error term. 
Considering the fact that states' demographic attributes data do not capture weekly or even daily changes and WFH and the pandemic information was limited by March, fixed effects would be limited. We therefore also estimated population-averaged generalized linear panel-data models with the GEE approach described in Liang and Zeger (1986). This longitudinal data model do not require the data set to be balanced and allows among- and within-state covariates to be incorporated straightforwardly. Although the model incorporates an assumption of multivariate normality of a response vector conditional on covariates, with large samples, estimators of parameters in the models are consistent for the true values with a deduced approximate normal sampling distribution.

In addition, we also add in industry sector controls in our modeling. Dingel and Neiman (2020) demonstrated industry sector variations in WFH feasibility in the pandemic. Bartik, et al. (2020b) also noted industries that are better suited to remote work seem to experience less productivity loss when switching to remote work. We therefore first integrate industry sector fixed effects to the population-averaged generalized linear panel-data models with the GEE approach. Then we adopted the two-level (i.e., state and industry sector) mixed-effects model.

As our theoretical framework noted, WFH is subject to local labor market conditions as well as industry sectors. Individual businesses are interdependent not only in an area where knowledge, information, labor, and social networks flow and spillover easily, but also correlated in the same industry sector. In this case, fixed-effect logistic regression is limited, because the assumed independent and identical distribution between individual observations is violated (McCoach \& Adelson 2010) and it does not allow for necessary random effects with an industry sector or a local areas. Multilevel modeling also enjoys the advantage of allowing for unbalanced sample size across local areas (Raudenbush 1993) shown in this study, compared to clustered standard errors. We want to observe not only variations across states (fixed state effects) but also random variations across industry sectors (random industry sector effects). In panel data, random effects are useful for modeling intra-industry sector; that is, states in the same industry sector are correlated because they share common industry sector level random effects. Mixed-effects modeling contains both fixed effects and random effects:

$$
\begin{aligned}
& \text { WFH }_{j k t}=\beta_{0}+\beta_{1} \text { AfterSHO }_{j k t}+\gamma_{i} \sum_{i=1}^{4} \operatorname{COVID}_{j k(t-1)}+\eta_{i} \sum_{i=1}^{3} \operatorname{ECON}_{j k(t-1)} \\
& +\theta_{i} \sum_{i=1}^{4} \text { Demographics }_{j k(t-1)}+Z_{j k t} \mu_{k t} .
\end{aligned}
$$

In our two-level mixed-effects panel data model, states are conditional on a set of random effects $\mu_{k t}$, for $k=$ $1, \ldots . n$ industry sectors, with industry sector $j$ consisting of $j=1, \ldots . m(m<=51)$ states' observations across time periods 
(days or weeks) $t$. Vector $Z_{j k t}$ is the covariate corresponding to the random effects. The random effects $\mu_{k t}$ are $n$ realizations from a multivariate normal distribution, with mean 0 and variance $\delta$. The random effects are not directly estimated as model parameters, but are instead summarized according to the unique elements of variance. Multilevel mixed-effects modeling have been used extensively in social science studies, such as Rabe-Hesketh and Skrondal (2012), which analyzes school data from Scotland.

To teste Hypotheses 2, we adopted three similar models. In this case, our dependent variable is business performance, Business $s_{j t}$, which captures operating revenue, cash flow, temporary closure, or disruption of supply chain. Since financial assistance from Paycheck Protection Program (PPP) and other programs might impact firms' revenue, cash, and performance, we include $F I N_{j(t-1)}$ to capture nine financial assistance types. The base model, the fixed-effect panel-data model, is therefore:

$$
\begin{aligned}
& \text { Business }_{j k t}=\beta_{0}+\beta_{1} \text { WFH }_{j k(t-1)}+\beta_{2} \text { AfterSHO }_{j t}+\gamma_{i} \sum_{i=1}^{4} \operatorname{COVID}_{j k(t-1)}+\eta_{i} \sum_{i=1}^{3} \operatorname{ECON}_{j k(t-1)} \\
& +\theta_{i} \sum_{i=1}^{4} \text { Demographics }_{j k(t-1)}+€_{i} \sum_{i=1}^{9} \operatorname{FIN}_{j(t-1)}+v_{j}+\varepsilon_{j t} .
\end{aligned}
$$

The two-level mixed-effects model accordingly changes to

$$
\begin{aligned}
& \text { Business }_{j k t}=\beta_{0}+\beta_{1} \text { WFH }_{j k(t-1)}+\beta_{2} \text { AfterSHO }_{j t}+\gamma_{i} \sum_{i=1}^{4} \operatorname{COVID}_{j k(t-1)}+\eta_{i} \sum_{i=1}^{3} \operatorname{ECON}_{j k(t-1)} \\
& +\theta_{i} \sum_{i=1}^{4} \text { Demographics }_{j k(t-1)}+€_{i} \sum_{i=1}^{9} \operatorname{FIN}_{j(t-1)}+Z_{j k t} \mu_{k t} .
\end{aligned}
$$

Based on our theory and hypothesis, we expect our independent variable $W F H_{j k(t-1)}$ to show a positive effect on our measures of business performance, Business $j k t$.

\section{Data Sources and Variable Measures}

Our main models to test Hypothesis 1 used daily data, starting from March 21, 2020 when the first state started the SHO till July 28, 2020, the last day we got our data, With one day lagged value for our independent variables, the daily data actually covers up to 130 days (depending on when a states starts the SHO) from March 20 to July 28, 2020 across all states (including DC) in the United States. Our data to test Hypothesis 2 are weekly data and include the small business data of April 26 through June 27, 2020. With one week lagged value for our dependent variables, the weekly data therefore covers 10 weeks from April 19 to June 27, 2020 over all states (including DC).

Our data comes from multiple data sources. Data for our key variable, $W F H$, are from the University of Maryland's Maryland Transportation Institute (MTI). WFH captures the daily percentage of workforce working from 
home. It is calculated using daily mobile device ${ }^{1}$ location based work trip information and US Department of Labor's unemployment claims information. According to Zhang, et al. (2020), MTI first integrated and cleaned location data from multiple sources representing person and vehicle movements to improve the quality of the mobile device location data panel and then clustered the location points into activity locations and identified home and work locations at the census block group level to protect privacy. If an anonymized individual in the sample did not make any trip longer than one-mile in distance, this anonymized individual was considered as staying at home. The data sources and computational algorithms have been validated based on a variety of independent datasets such as the National Household Travel Survey and American Community Survey (ACS), and peer reviewed by an external expert panel in a U.S. Department of Transportation Federal Highway Administration's Exploratory Advanced Research Program project².

The data for small business performance measures are from the US Census Bureau weekly Small Business Pulse Survey (SBPS). The survey targets toward all nonfarm, single-location employer operating businesses with 1-499 employees and receipts of $\$ 1,000$ or more in the 50 states, DC, and Puerto Rico. For those single-establishment small businesses, the decision to choose WFH often falls on business owners or top executives. The survey does not include businesses in agriculture, railroads, US Postal Service, Central Bank, Funds, Trusts, and other financial vehicles, religious grant operations and religious organizations, private households, public administration, or with unclassified legal form of organizations as tax-exempt or unknown.

As a survey conducted by the US Census Bureau, the survey represents the country's small businesses relatively well. As an online survey and with the sample restricted to businesses with e-mail addresses, the SBPS survey data comes with a potential selection issue, if businesses willing to participate in email-based surveys are systematically different from other businesses, However, since our study is on WFH, the online survey works better for businesses that could potentially allow WFH. The SBPS may be subject to non-response bias because of lack of response or because some may have already closed; however, according to Buffington et al. (2020), the estimates in the data have been re-weighted to adjust for non-response based on prior employment size. In addition, as Buffington et al. (2020) noted, although the businesses sampled in the SBPS tend to be larger than the average small business, they do not appear to differ substantially in terms of firm age.

\footnotetext{
${ }^{1}$ Daily feeds of more than 100 Million anonymized devices are used.

2 Titled "Data analytics and modeling methods for tracking and predicting origin-destination travel trends based on mobile device data".
} 
Our business performance measures include the percentages of small business that increased (or decreased) operating revenues and experienced (or not) temporary closure, disruptions in supply chain, no cash flow or cash on hand for 1-4 weeks, 1-2 months, or 3 months or more. SBPS provides detailed information on the challenges that small businesses are facing during the COVID-19 pandemic as well as related financial assistance programs such as the PPP.

The main COVID-19 pandemic severity measures (COVID new cases and COVID death rate) are sourced from Johns Hopkins University (JHU) Center for Systems Science and Engineering (CSSE) Github data repository. The COVID new cases is measure by the number of COVID cases per 1000 people. COVID death rate is measured as the percentage of deaths among all COVID-19 cases. The CSSE repository is widely used since the start of pandemic. Funded by multiple agencies and prestigious institutions ${ }^{3}$, the CSSE data for the United States are from U.S. county and state health departments, multiple national government health departments, and data aggregating websites ${ }^{4}$ combining reports from local health departments and media reports (Dong et al. 2020).

Our data for days of decreasing COVID cases and COVID exposure are calculated by the MTI. Days of decreasing COVID cases is used because one federally recommended guideline to reopen is a decline in cases over 14-day period $^{5}$. Since many states reopened and ended the SHO without meeting the federal guideline, we feel it necessary to include this measure in our model to better control the pandemic severity. It measures the number of days with decreasing COVID-19 cases. Since COVID caseload and death rates are subject to the test availability and people's behavior that differ across areas, to fully measure the pandemic severity, we also added a measure, COVID exposure which captures the number of residents already exposed per 1000 people.

The SHO data $\left(\right.$ AfterSHO $\left._{j t}\right)$ are from the U.S. COVID-19 Hospital Needs and Death Projections data, compiled by the Institute for Health Metrics and Evaluation (IHME), University of Washington (IHME 2020). The earliest SHO started on March 21. Our data focus on the observations since the first SHO started. Therefore $A f \operatorname{terSHO} \mathrm{j}_{\mathrm{j}}$ has two values: 0 for when SHO was in effect and 1 for after the SHO ended.

For the economic background data, the unemployment rates are weekly from the US Department of Labor (USDOL). The median household income is again from the ACS. Employment density information is from the US Environmental Protection Agency (EPA)'s Smart Location Database (SLD). It captures jobs per acre on unprotected

\footnotetext{
${ }^{3}$ e.g., the JHU, National Science Foundation, National Institute of Allergy and Infectious Diseases and National Aeronautics and Space Administration (NASA), Bloomberg Philanthropies, Stavros Niarchos Foundation.

${ }^{4}$ Those websites Include 1point3acres, Worldometers.info, BNO, and the COVID Tracking Project.

${ }^{5}$ See https://www.whitehouse.gov/openingamerica/.
} 
land. According to EPA (2020), the Smart Location Database is a nationwide geographic data resource for measuring location efficiency for over 90 attributes summarizing characteristics (such as housing density, neighborhood design, destination accessibility, transit service, employment); most of them are available for every census block group.

The demographic data are from the ACS and include percentages of men, African Americans, Hispanic Americans, older Americans aged 60 or above. For the influence of financial assistance, in addition to the $P P P$, other controlled financial assistance programs in the models include assistance from the Economic Injury Disaster Loans (EIDL), SBA Loan Forgiveness, Other Federal Programs, State or Local Government, banks, self-fund, family, friends, and others. Table 1 list the data source, type, time period, and measure for each variable.

$$
<<\text { Insert Table } 1 \text { about here }>>
$$

\section{Findings}

Since our data has two cuts: (1) daily data from March 20 to July 28, and (2) weekly from April 19 to June 27, 2020, we describe our findings using those two cuts separately. Although when adding industry sector information, the number of observations increased, the data attributes do not change substantially.

For the daily data, there are 4,551 observations across up to 130 days, 51 states (including Washington DC). Across states we see vast disparities. Over our observation period, averagely $27 \%$ of the US workforce since the start of states' $\mathrm{SHO}$ worked from home, ranging from the lowest rate in a state at only $5 \%$ to the highest at $56 \%$; daily new COVID caseload was about 122 cases per 1 million people with the mean death rate at about 1.7\%; about 12 out of 1000 people were exposed to the COVID-19; the average number of days of decreased caseload was less than 4 days. While the mean unemployment rate across all states during this period is $21.5 \%$, it varies from the lowest at $8 \%$ to the highest at $44 \%$. The median household income was around $\$ 63,000$, but the highest state almost doubled that of the lowest state's value. Similarly we see large racial distribution disparities across states.

\footnotetext{
$<<$ Insert Table 2 about here $>>$
}

Appendix Table A presents the correlation matrix between those variables. We do not detect potential major concerns for multicollinearity. 
Figure 1 shows related (either similar or opposite) trends between WFH, COVID new caseload, unemployment rate, and time (the start and end of the SHO). Since the start of SHO (starting on March 21, 2020 in some states), new COVID caseload and WFH were dropping and unemployment rate was rising until around the time when the SHO ended (starting on April 25, 2020 in some states). Soon after the SHO started to end, the unemployment rate started to tip down, and WFH and new COVID caseload started to tick up in June. Figure A in Appendix shows detailed variations across states.

$<<$ Insert Figure 1 about here $>>$

The intuition from Figure 1 seem to show that the WFH rate change is almost a catching up following the COVID new caseload changes and unemployment rate. After controlling for the pandemic and unemployment changes, does the WFH rate change becomes irrelevant? Although the WFH rate has kept rising after the SHO ended, by the time we conducted this study it has not yet returned to the peak when SHO started, reflecting a very moderate negative correlation between WFH and the end of SHO (shown in Table A in Appendix), opposite to our Hypothesis 1 expectation.

We therefore estimated multivariate empirical models of this impact, controlling for the local pandemic, economic and demographic conditions, as shown in Table 3. Model (1) and (2) adopted the fixed-effect panel data models. Model (3) and (4) adopted the population-averaged generalized linear panel-data models with the GEE approach. Models (1) and (3) included the time variable, Date, to add the fixed time effect, in addition to the fixed state effects in Models (2) and (4). All the four models used the daily data and resulted in 4,551 observations.

Across all the four models, WFH demonstrated a consistently strong and higher rate after the SHO ended, controlling for the local pandemic, economic, and demographic conditions. Models (2) and (4) show that WFH rate is about 2 percentage points higher after versus before the SHO ended. Models (1) and (3) show an average 0.03 percentage point daily increase in WFH rate since the SHO started in addition to a 0.5 percentage point increase in WFH rate after the SHO ended. 
This effect is also presented in Figure 2. After the SHO ended, the policy requirement restricting workers to commute to work was lifted. However when holding local pandemic, economic, and demographic factors constant, this did not result in a drop in the WFH rate; instead, WFH rate continued to rise. This is consistent with our expectation in Hypothesis 1. All the four models also clearly evidenced the pandemic and economic impact on WFH rates.

$<<$ Insert Figure 2 about here $>>$

For our weekly data, most variable summary statistics (shown in Appendix Table B) are similar to that of our daily data, except that the number of observation dropped to 687 overall and to 333 for small business measures. Among all the observing small businesses, only $2 \%$ of them reported no cash flow at all, $31 \%$ reported cash flow to last about $1-4$ weeks, $29 \%$ reported cash flow to last 1-2 months, and 23\% reported cash flow to last 3 months or longer. While all states have more small businesses reporting a decreasing versus increasing in operating revenue (shown in negative range), averagely across all states and observing period, 34 percentage of more businesses reported decreasing than increasing operating revenue. While some state in a certain week reported as high as $29 \%$ of small businesses experienced temporary closures, overall most small business did not experience temporary closure. The number of small businesses that did not report temporary closures in the survey is 46 percentage point higher than those that did. While some state reported as high as $8 \%$ of business experienced disruption of supply chain, the number of small businesses that did not report disruption of supply chain is 24 percentage points higher than those that did in the survey.

Considering the fact the WFH rate is much affected by the pandemic and economic conditions (as shown in Table 2), estimating the WFH effect on small business performance needs to control for local pandemic, economic, and demographic conditions. We first conducted four sets of empirical models with those controls, as well as industry sectors, to test Hypothesis 2. Appendix Table C Models (5) through (11) presents the estimates in seven two-level mixed-effects models, each on one business performance measure.

Considering the potential impact of PPP and other financial assistance programs, we also added the financial assistance control variables in our models in Table 1. The WFH effects on small business performance shown in Table 4 stayed highly similar to those shown in Appendix Table C.

$<<$ Insert Table 4 about here $>>$ 
As Models (12) through (18) in Table 4, as well as Models (5) through (11) in Appendix Table C, show, a higher

WFH rate is associated with a better performance for small businesses when controlling for local pandemic, economic and demographic conditions: one percentage point increase in the WFH rate is associated with a small businesses' share increase for (1) a cash flow lasting 1week to 3 month or more, (2) increasing operating revenue, (3) no temporary closures, and (4) no disruptions in supply chain. Our models also show that the pandemic has negative impacts on small business performances, consistent with previous literature (see Bartik, et al. 2020a). Although the COVID pandemic itself naturally bring economic shock to small businesses (such as a decrease in operating revenue, temporary closures, and disruption in supply chain as shown in Table 4), WFH helped offset small businesses some of those negative shocks, as expected in Hypothesis 2.

As Models (12) through (15) shows, while a higher WFH rate does not increase the percentage of small businesses that have no cash flow reserved at all, it is associated with a higher share of small businesses with cash flow reserve for 1-4 weeks, 1-2 months, or 3 or more months respectively by $0.14,0.45$, and 0.35 percentage points, when holding local pandemic, economic, demographic, and financial assistance conditions constant. Figure 3 partially illustrates those effects for observations with the WFH rates for $99.3 \%$ of the observation without the two extreme tails. ${ }^{6}$ Noting that the impact is stronger for cash flow reserves longer than one month. Since businesses that have longer cash flow reserves were probably slightly larger, this is consistent with the finding from the literature (see Aguilera, et al. 2016) that larger businesses are more likely to adopt WFH.

$<<$ Insert Figure 3 about here $>>$

Model (16) demonstrates the WFH effect on small businesses' operating revenue increase. When controlling for local pandemic, economic, and demographic conditions, each one percentage point increase in a state's WFH rate is associated with a 0.6 percentage point net increase in the small businesses' operating revenue a week later. This positive WFH effect is reflected in Figure 4 with 95\% confidence interval. The left panel of Figure 4 presents the WFH effect for the $99.3 \%$ of the observation without the two extreme tails; the right panel is for all observations.

\section{$<<$ Insert Figure 4 about here $>>$}

\footnotetext{
${ }^{6}$ Figures 3 partially illustrates those effects. Figure 3 omitted observations for WFH rate below $3 \%$ and above $50 \%$ (i.e., omitting the two extreme tails at $3 \%$ and $50-56 \%$ ) because those observation only represent $0.7 \%$ of the observation, but have a much larger and more dramatic effect from WFH rates. Presenting those in the graph will visually inflate the WFH effects.
} 
As shown in Model (17), ceteris paribus, a percentage point increase in states' WFH rates resulted in 0.8 percentage point decrease in the small businesses' probability of temporarily closures. The left panel of Figure 5 presents the WFH effect without the two tiny tails; the right panel is for all observations.

$<<$ Insert Figure 5 about here $>>$

Model (11) shows that each one percentage point increase in states' WFH rates resulted in 0.4 percentage point decrease in small businesses' probability of supply chain disruptions, ceteris paribus. The left panel of Figure 6 presents the effect without the tiny tails; the right is for all observations.

$<<$ Insert Figure 6 about here $>>$

The financial assistance from PPP (shown in Table 4) has a positive effect on small business cash flow, temporary closures, and disruptions in supply chain. This reflects the importance of PPP. However, PPP show a negative effect on small businesses' increase in operating revenue, reflecting the fact that businesses receiving assistance from PPP tended to have lower operating revenue.

This positive WFH rate effect on small business performance in Models (5)-(18) ${ }^{7}$ and Hypothesis 2 further confirms our theory and Hypothesis 1 . This positive effect confirms WFH as a business rational option and is a driving force for the rising WFH rates even after SHO ended.

\section{Robustness Check}

To gauge the robustness of our empirical form, we not only ran three types of models, we also added different variables to check whether the effects are consistent. As mentioned above, adding time effects in Models (1) and (3) in Table 3 or adding controls for financial assistance programs in Models (12)-(18) in Table 4, our findings are consistent and highly similar respectively to Models (2) and (4) in Table 3 or Models (5)-(11) in Appendix Table C.

\footnotetext{
${ }^{7}$ Models (12) through (18) are in Table 4 and Models (5) through (11) are in Appendix Table C.
} 
We also estimated alternative models. For Hypothesis 1, we further estimated Models (19)-(22) in Appendix Table D using weekly, instead of daily, data, including fixed industry sector effects, and with the three aforementioned types of models. All those models show the same strong rising WFH trends after the SHO ended, consistent with Models (1) through (4) using daily data presented in Table 3,

For Hypothesis 2, to check the robustness of our two-level mixed-effects models [Models (5) through (18)] that tested Hypothesis 2, again we estimated a set of fixed-effects panel data models [Models (23) -(29) in Appendix Table E], population-averaged generalized linear panel-data models with the GEE approach [Models (30)- (36) in Appendix Table F], and population-averaged generalized linear panel-data models with the GEE approach with fixed industry sector effects [Models (37)-(43) in Appendix Table G]. The positive business effects we found in our two-level mixed-effects

models [Models (5) through $(18)^{8}$ ] are basically the same as the population-averaged generalized linear panel-data models with the GEE approach and fixed industry sector effects [Models (37) through (43) in Appendix Table G] and not inconsistent with the other models as well.

The highly consistent effects across the 43 models indicate the robustness of our models. Also, among the fixedeffects models, those testing Hypothesis 1 explained 33\% to 43\% of variability of WFH; those testing Hypothesis 2 explained lower variability (up to $12 \%$ ) for small business performance measures because the relatively limited number of observations with the weekly data. All those models have a statistically significant F statistics. The chi-square tests are statistically significant for all the population-averaged generalized panel-data models with the GEE approach and twolevel mixed-effects models. The latter also have high log likelihoods and show significant difference from linear models via the likelihood ration tests, indicating the advantage of controlling both state and industry sector level variations.

\section{Discussion}

Following Schumpeter (1934)'s “creative destruction” argument, although COVID-19 resulted a human health and economic disaster, this destruction may result in some new creations, innovations, and creative ways to better utilize our advances in high-tech communication platforms. This "creative destruction", expedited by the painful COVID-crisis, may have sped up our learning curve for using and accepting high-tech communication platforms as a norm; this could set a more efficient and more cost-effective new course of production in the long run. The forced new WFH norm may have

\footnotetext{
${ }^{8}$ Models (12) through (18) are in Table 4 and Models (5) through (11) are in Appendix Table C.
} 
not only expedited WFH-ready firms to implement WFH practice more fully, but may also push other firms to creatively find new solutions to utilizing the modern communication technology in any possible creative ways. Out of this disruption, not only our health care system can be reborn mending many exposed weaknesses, the potential of WFH could be more fully realized. A disruption from the traditional brick-\&-mortar offices might result in a new hybrid or a WFHdominant new workplace setting. If the new WFH norm really emerges soon, our current human resource practice, real estate industry, urban sprawling patterns, urban planning, racial segregation, city externalities would all await to be transformed. This would have huge public policy implications.

More importantly and sadly, the rising WFH popularity would deepen the digital divide and widen the wealth gap. Dingel \& Neiman (2020) noted lower-income economies have a lower share of WFH jobs. Those who haves and havenots would be increasingly different, unless more and more jobs can be done via WFH. Otherwise the world would be more polarized, like what education has divided us in the long human history: on the one hand, high skilled workers who master digital skills are not only enjoy better pay, better work-life balance (Mas \& Pallais 2017) and better control of their schedules, but also better health with limited exposure to virus or bacteria; on the other hand, workers without digital skills or digital access often conduct relatively low-paid jobs, remain a life demanded by their bosses' schedules, and more importantly, always at the front line to be exposed to any transmutable disease, virus, germs. Dingel \& Neiman (2020)'s contribution on teleworkable jobs offered the timely and critical contribution in the pandemic. When WFH really becomes the new norm, we hope certain innovation can penetrate WFH better to currently non-teleworkable jobs eventually. This requires entrepreneurship from often the nimble and creative small businesses.

The internet and globalization are double edged swards: they on the one hand reached out better to the poor with a larger market, on the other hand made it easier for the large firms to sell and profit more. WFH would further make the internet and globalization a necessity.

WFH itself is a double-edged sword as well. It not only brings the flexibility and a better work-family balance to workers [c.f. Gajendran, et al (2007)], but also often blurs the boundaries between work and family (Riggoti et al. 2020). There is also general managerial concern on control and surveillance for WFH workers (Coenen and Kok 2014), or a career path concerns with limited in-person presence (Golden and Eddleston 2020), both related to an appropriate psychosociological distance (Belanger, 1999; Taskin and Devos 2005; Wilton et al., 2011). Best practice human resources policies need to be further discussed for a healthy and sustaining labor relations. 
This paper used small business data because small business are often the most vulnerable in the crisis. It is not our intention to compare the WFH effects for small businesses to that for larger businesses. Small businesses often do not have as much resources as larger businesses to build robust WFH infrastructure (Vilhelmson and Thulin 2016), including costs of organizational change and technological investments (Aguilera, et al. 2016). This could have limited some of our evidence. Since we found positive productive role of WFH in small business performance, the impacts for larger businesses could be even larger. Although we do not have data on business owners or decision making process, for the timeliness and limitation of the data availability, this paper relies on the best available data that is publicly available and well-represented to empirically test the WFH effects.

In this COVID-19 pandemic, social distancing is critical. Whether a small business can adjust its goods and service to pickup/carry-out/delivery as their only means to serve customers shows how nimble and adaptive to change a small business is. This could also be related WFH. We initially planned to also model WFH effects on this. However, it is unclear what types of impact can be expected. Further analysis on this will need to be considered. In addition, fear factor could affect economic recovery in the pandemic and its aftermath. Before the effective vaccine is found and prevalent, this fear factor could affect the WFH trajectory. Further research is needed on that.

\section{Conclusion}

The study first builds a theoretical framework based on utility maximization theory subject to a "contagion" agglomeration parameter and argues that WFH is a rational choice for small businesses. We then compiled an up-to-date real-time daily and weekly multifaceted data set tracking WFH propensity from March 20 through July 28. Using this data set, we estimated a variety of fixed-effects panel data models, population-averaged generalized linear panel-data models with the GEE approach, and two-level mixed-effects panel-data models.

Our empirical findings are consistent with our initial expectation and also support the hypotheses drawn from our theoretical framework. First, WFH has potential attractiveness for employers. In the pandemic, although WFH rate is dramatically increased due to the COVID pandemic and the SHO mandate, after the SHO ended, WFH rate did not drop and instead rose, after controlling for local pandemic, economic, and demographic conditions. This paper empirically supports the idea that WFH could be the new norm. 
With various economic and health advantages, WFH has been shown in this study to positively associate with small business' operating revenue increases, stronger cash flow positions, and reductions in temporary closure and in supply chain disruption. These help mitigate the negative pandemic shock and suggest that a policy response include provisions to promote teleworkable jobs and WFH.

More importantly, if this pandemic brings in major economic structure disruption, WFH could be the opportunity for Schumpeterian "creative" innovation out of this disruption. As nimble and creative as small businesses have always been, riding or even leading this WFH wave well would not only help small businesses survive better in the pandemic, it might make them the vanguard of a new work paradigm. With public policy facilitating WFH with technology and institution, this new potential may really happen.

\section{References}

Aguilera, A., Lethiais, V., Rallet, A. \& Proulhac, L. (2016). Home-based telework in France: Characteristics, barriers and perspectives, Transportation Research Part A, 92 (2016) 1-11

Bade, R. \& Parkin, M. (2018). Essential Foundations of Economics (8th Edition). Pearson. https://www.pearson.com/us/higher-education/program/Bade-Essential-Foundations-of-Economics-Plus-My-LabEconomics-with-Pearson-e-Text-Access-Card-Package-8th-Edition/PGM1806562.html.

Bailey, D.E., Kurland, N.B., (2002). A review of telework research: findings, new directions, and lessons for the study of modern work. J. Org. Behav. 23 (4), 383-400.

Bartik, A. W., M. Bertrand, Z. B. Cullen, E. L. Glaeser, M. Luca, and C. T. Stanton (2020a April). How are small businesses adjusting to covid-19? early evidence from a survey. Working Paper 26989, National Bureau of Economic Research.

Bartik, A. W., Z. B. Cullen, E. L. Glaeser, M. Luca, and C. T. Stanton (2020b June). What job are being doen at home during the COVID-19 crisis? evidence from firm-level surveys. Working Paper 27422, National Bureau of Economic Research. http://www.nber.org/papers/w27422. 
Bartz, W. \& Winkler, A., (2016). Flexible or fragile? The growth performance of small and young businesses during the global financial crisis - Evidence from Germany, Journal of Business Venturing, 31(2), http://dx.doi.org/10.1016/j.jbusvent.2015.10.002.

Belanger, F., (1999). Workers' propensity to telecommute: an empirical study. Inf. Manage. 35, 139-153.

Belzunegui-Eraso, A., \& Erro-Garcés, A. (2020). Teleworking in the Context of the Covid-19 Crisis. Sustainability, 12(9), 3662.

Bourdeau, S., Ollier-Malaterre, A., \& Houlfort, N. (2019). Not all work-life policies are created equal: Career consequences of using enabling versus enclosing work-life policies. Academy of Management Review, 44(1), 172193.

Breman (2020). U.S. Workers Discovering Affinity for Remote Work, Economy, Gallup, April 3, 2020, https://news.gallup.com/poll/306695/workers-discovering-affinity-remote-work.aspx.

Buffington, C., Dennis, C., Dinlersoz, E., Foster, L., \& Klimek, S. (2020). Measuring the Effect of COVID-19 on U.S. Small Businesses: The Small Business Pulse Survey, U.S. Census Bureau, Center for Economic Studies Discussion paper, CES 20-16, https://www2.census.gov/ces/wp/2020/CES-WP-20-16.pdf.

Caillier, J. G. (2012). The impact of teleworking on work motivation in a U.S. federal government agency. American Review of Public Administration, 42(4), 461-80.

Coenen, Marja and Robert A.W. Kok. (2014). Workplace Flexibility and New Produce Development Performance: The role of Telework and Flexible Work Schedules. European Management Journal, 32(4), August 2014, pp. $564-576$.

Dingel, J. I., and B. Neiman (2020): How Many Jobs Can be Done at Home?, Working Paper 26948, National Bureau of Economic Research.

Dong E, Du H, Gardner L. (2020). An interactive web-based dashboard to track COVID-19 in real time. Lancet Infect Dis; published online Feb 19. https://doi.org/10.1016/S1473-3099(20)30120-1.

Eaton, S. C. (2003). If you can use them: Flexibility policies, organizational commitment, and perceived performance. Industrial Relations: A Journal of Economy and Society, 42(2), 145-167.

Environmental Protection Agency (EPA) (2020). Smart Location Database, accessed on Aug 6, 2020 at the World Wide Web https://www.epa.gov/smartgrowth/smart-location-mapping\#SLD.

Gajendran, R. S., \& Harrison, D. A. (2007). The good, the bad, and the unknown about telecommuting: Meta-analysis of psychological mediators and individual consequences. Journal of Applied Psychology, 92(6), 1524-41. 
Gajendran, R. S., Harrison, D. A., Delaney-Klinger, K. (2014). Are telecommuters remotely good citizens? Unpacking telecommuting's effects on performance via i-deals and job resources. Personnel Psychology, 68, 353-393. doi:10.1111/peps.12082.

Glaeser, E. (1999), Learning in Cities, Journal of Urban Economics, Volume 46, Issue 2, September 1999, Pages 254277.

Golden, Timothy D. and Kimberly A. Eddleston. (2020) Is there a Price Telecommuters Pay? Examining the Relationship between Telecommuting and Objective Career Success, Journal of Vocational Behavior, 116 (2020). https://doi.org/10.1016/j.jvb.2019.103348.

Helminen, V., Ristimäki, M., (2007). Relationships between commuting distance, frequency and telework in Finland. $J$. Transp. Geogr. 15 (5), 331-342.

Institute for Health Metrics and Evaluation (IHME) (2020). COVID-19 Mortality, Infection, Testing, Hospital Resource Use, and Social Distancing Projections. Seattle, United States of America: Institute for Health Metrics and Evaluation (IHME), University of Washington, 2020.

Kennickell, A. B., Kwast, M. L., \& Pogach, J. (2017). Small Businesses and Small Business Finance during the Financial Crisis and the Great Recession: New Evidence from the Survey of Consumer Finances, in John Haltiwanger, Erik Hurst, Javier Miranda, and Antoinette Schoar (eds), Measuring Entrepreneurial Businesses: Current Knowledge and Challenge, University of Chicago Press, pp. 291-349,http://www.nber.org/chapters/c13496.

Kelliher, C., \& Anderson, D. (2010). Doing more with less? Flexible work practices and the intensification of work. Human Relations, 63(1), 83-106.

Kitou, E. \& Horvath, A., (2008). External air pollution costs of telework. Int. J. Life Cycle Assess. 13 (2), $155-165$.

Kolasa,M., Rubaszek,M., Taglioni, D., (2010). Firms in the great global recession: the role of foreign ownership and financial dependence. Emerg.Mark. Rev. 11, 341-357.

Krugman, P. (1996). Urban Concentration: The Role of Increasing Returns and Transport Costs, International Regional Science Review, 19(1-2). https://doi.org/10.1177/016001769601900202.

Mas, A. and Pallais, A. (2017). Valuing Alternative Work Arrangements, American Economic Review, 107(12): 37223759, https://doi.org/10.1257/aer.20161500.

Matthews, H.S., Williams, E., (2005). Telework adoption and energy use in building and transport sectors in the United States and Japan. J. Infrastruct. Syst. 11 (1), 21-30. 
McCoach, D.B., \& Adelson, J.L. (2010). Dealing with dependence (part I): Understanding the effects of clustered data.

Gifted Child Quarterly, 54, 152-155. DOI: DOI: 10.1177/0016986210363076.

Mokhtarian, P.L., Collantes, G.O., Gertz, C., 2004. Telecommuting, residential location, and commute distance travelled: evidence from State of California employees. Environ. Plan. 36 (10), 1877-1897.

Rabe-Hesketh, S., \& Skrondal, A. (2012). Multilevel and longitudinal modeling using stata (3rd ed.). College Station, TX: Stata Press.

Raudenbush, S.W. (1993), Hierarchical linear models and experimental design. In Lynne K., and Edwards, Applied analysis of variance in behavioral science, New York: Marcel Dekker

Ravi, S. G. \& David, A. H. (2007). The Good, the Bad, and the Unknown About Telecommuting: Meta-Analysis of Psychological Mediators and Individual Consequences. Journal of Applied Psychology, 92(6), 1524-1541. DOI: 10.1037/0021-9010.92.6.1524.

Redman, T., Snape, E. \& Ashurst, C. (2009). Location, Location, Location: Does Place of Work Really Matter? British Journal of Management, 20(1), 171-181. DOI: 10.1111/j.1467-8551.2008.00640.x.

Rigotti, T., De Cuyper, N., \& Sekiguchi, T. (2020). The Corona Crisis: What can we learn from earlier studies in Applied Psychology? [Editorial, Virtual Issue]. Applied Psychology: An International Review.

Saxenian, A.L, (1994). Regional Networks: Industrial Adaptation in Silicon Valley and Route 128, Cambridge, MA: Harvard University Press.

Schumpeter, J. A. (1934). The theory of economic development: An inquiry into profits, capital, credit, interest, and the business cycle. Cambridge, MA: Harvard University Press

SHRM. (2018). Leveraging Workplace Flexibility for Engagement and Productivity, https://www.shrm.org/hrtoday/trends-and-forecasting/special-reports-and-expertviews/Documents/Leveraging-Workplace-Flexibility.pdf, last accessed 2018/11/03.

Steven Ruggles, Sarah Flood, Ronald Goeken, Josiah Grover, Erin Meyer, Jose Pacas and Matthew Sobek (2020). IPUMS USA: Version 10.0 [dataset]. Minneapolis, MN: IPUMS, 2020. https://doi.org/10.18128/D010.V10.0.

Taskin, L., Devos, V., (2005). Paradoxes from the individualization of human resource management: the case of telework. Journal of. Business Ethics, 62, 13-24. 
Vilhelmson, B, Thulin, E (2016) Who and where are the flexible workers? Exploring the current diffusion of telework in Sweden. New Technology, Work and Employment, 31(1): 77-96.

Wheatley, D., (2012). Good to be home? Time-use and satisfaction levels among home-based teleworkers. New Technol., Work Employment, 27 (3), 224-241.

Wilton, R.D., Páez, A., Scott, D.M., (2011). Why do you care what other people think? A qualitative investigation of social influence and telecommuting. Transp. Res. Part A: Policy Pract. 45 (4), 269-282.

Zeger, S. L., and K.-Y. Liang. (1986.) Longitudinal data analysis for discrete and continuous outcomes. Biometrics, 42:121-130.

Zhang, L. Ghader,S., Pack, M.L., Xiong,C., Darzi,A., Yang, M., Sun, Q., Kabiri, A., \& Hu, S.(2020) An interactive COVID-19 mobility impact and socialdistancing analysis platform, MedRxiv, doi:

https://doi.org/10.1101/2020.04.29.20085472. 
Table 1. Data Sources, Types, Time Periods, Measures for all Variables

\begin{tabular}{|c|c|c|c|c|}
\hline Variable Name & Description & Source & $\begin{array}{l}\text { Time } \\
\text { Period }\end{array}$ & Data Type \\
\hline \multicolumn{5}{|c|}{ WFH: Work From Home } \\
\hline WFH & $\begin{array}{l}\text { Percentage of workforce working from home based on } \\
\text { UMD models. Calculated by MTI based on changes in } \\
\text { work trips and unemployment claims. }\end{array}$ & MTI & $\begin{array}{c}\text { 3/21-7/28, } \\
\text { daily }\end{array}$ & $\begin{array}{c}\text { Continuous } \\
(\%)\end{array}$ \\
\hline \multicolumn{5}{|c|}{ AfterSHO: After Stay-Home Order Ended } \\
\hline afterSHO & The date is later than the state's stay-home order end date & IHME & $\begin{array}{c}\text { 3/21-7/28, } \\
\text { daily }\end{array}$ & Dummy \\
\hline \multicolumn{5}{|c|}{ Business: Business Performance Measures } \\
\hline Opr Rev & $\begin{array}{l}\text { Percentage of businesses reported "increased" }(+) \text { or } \\
\text { "decrease" (-) to the question "In the last week, did this } \\
\text { business experience a change in operating revenues?" }\end{array}$ & SBPS & $\begin{array}{c}\text { 4/26-6/27, } \\
\text { weekly }\end{array}$ & $\begin{array}{l}\text { Continuous } \\
(\%)\end{array}$ \\
\hline Tenp Closure & $\begin{array}{l}\text { Percentage of businesses reported "yes" (+) or "no" (-) to } \\
\text { the question "In the last week, did this business } \\
\text { temporarily close any of its locations for at least one day?" }\end{array}$ & SBPS & $\begin{array}{l}4 / 26-6 / 27 \\
\text { weekly }\end{array}$ & $\begin{array}{l}\text { Continuous } \\
\quad(\%)\end{array}$ \\
\hline Disrpt. Sup Chn & $\begin{array}{l}\text { Percentage of businesses reported "yes" (+) or "no" (-) to } \\
\text { the question "In the last week, did this business have } \\
\text { disruptions in its supply chain?" }\end{array}$ & SBPS & $\begin{array}{c}\text { 4/26-6/27, } \\
\text { weekly }\end{array}$ & $\begin{array}{l}\text { Continuous } \\
\quad(\%)\end{array}$ \\
\hline cashFlow0 & $\begin{array}{l}\text { Percentage of businesses reported "No cash available for } \\
\text { business operations" to the question "How would you } \\
\text { describe the current availability of cash on hand for this } \\
\text { business?" }\end{array}$ & SBPS & $\begin{array}{l}4 / 26-6 / 27 \\
\text { weekly }\end{array}$ & $\begin{array}{l}\text { Continuous } \\
(\%)\end{array}$ \\
\hline cashFlow $4 \mathrm{w}$ & $\begin{array}{l}\text { Percentage of businesses reported "1-4 weeks of business } \\
\text { operations" to the question "How would you describe the } \\
\text { current availability of cash on hand for this business?" }\end{array}$ & SBPS & $\begin{array}{l}4 / 26-6 / 27 \\
\text { weekly }\end{array}$ & $\begin{array}{l}\text { Continuous } \\
\quad(\%)\end{array}$ \\
\hline cashFlow $2 \mathrm{~m}$ & $\begin{array}{l}\text { Percentage of businesses reported "1-2 months of business } \\
\text { operations" to the question "How would you describe the } \\
\text { current availability of cash on hand for this business?" }\end{array}$ & SBPS & $\begin{array}{l}4 / 26-6 / 27 \\
\text { weekly }\end{array}$ & $\begin{array}{l}\text { Continuous } \\
\quad(\%)\end{array}$ \\
\hline cashFlow $3 \mathrm{~m}+$ & $\begin{array}{l}\text { Percentage of businesses reported " } 3 \text { or more months of } \\
\text { business operations" to the question "How would you } \\
\text { describe the current availability of cash on hand for this } \\
\text { business?" }\end{array}$ & SBPS & $\begin{array}{l}4 / 26-6 / 27 \\
\text { weekly }\end{array}$ & $\begin{array}{l}\text { Continuous } \\
\quad(\%)\end{array}$ \\
\hline \multicolumn{5}{|c|}{ COVID: COVID-19 Pandemic Severity } \\
\hline New Case / 1k & $\begin{array}{l}\text { Number of COVID-19 daily new cases per } 1000 \text { people } \\
\text { (three-day moving average). }\end{array}$ & CSSE & $\begin{array}{l}3 / 20-7 / 28 \\
\quad \text { daily }\end{array}$ & $\begin{array}{l}\text { Continuous } \\
(0 / 000)\end{array}$ \\
\hline Death Rt & $\begin{array}{l}\text { \% deaths among all COVID-19 cases. Calculated by MTI } \\
\text { based on number of deaths and estimated total COVID } \\
\text { cases including confirmed and untested cases. }\end{array}$ & CSSE & $\begin{array}{l}3 / 20-7 / 28 \\
\text { daily }\end{array}$ & $\begin{array}{l}\text { Continuous } \\
(\%)\end{array}$ \\
\hline exposure / $1 \mathrm{k}$ & $\begin{array}{l}\text { Number of residents already exposed to coronavirus per } \\
1000 \text { people. Calculated by MTI. }\end{array}$ & MTI & $\begin{array}{l}3 / 20-7 / 28 \\
\text { daily }\end{array}$ & $\begin{array}{l}\text { Continuous } \\
(0 / 000)\end{array}$ \\
\hline Days Decr. & $\begin{array}{l}\text { Number of days with decreasing COVID-19 cases. } \\
\text { Calculated by MTI based on weekly pattern of new daily } \\
\text { cases. }\end{array}$ & MTI & $\begin{array}{l}3 / 20-7 / 28 \\
\text { daily }\end{array}$ & Continuous \\
\hline \multicolumn{5}{|c|}{ ECON: Economic Background } \\
\hline Unemploy Rt & Unemployment rate updated weekly. & USDOL & $\begin{array}{c}3 / 15-7 / 28 \\
\text { weekly }\end{array}$ & $\begin{array}{c}\text { Continuous } \\
(\%)\end{array}$ \\
\hline
\end{tabular}




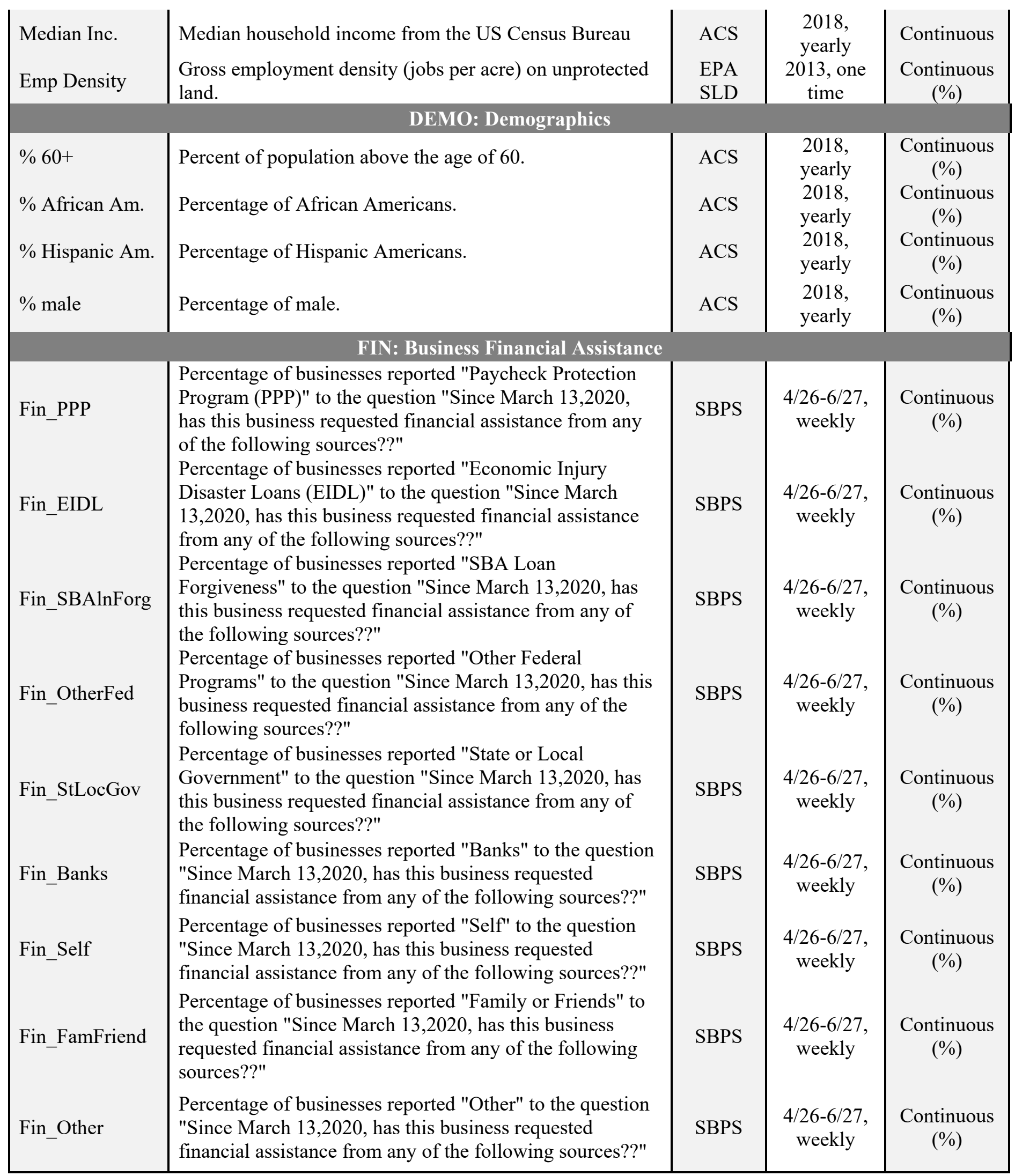


Table 2. Descriptive Statistics for Daily Data

\begin{tabular}{|c|c|c|c|c|c|}
\hline Variable & Obs & Mean & Std. Dev. & Min & Max \\
\hline \multicolumn{6}{|c|}{$\overline{\text { WFH }}$} \\
\hline WFH & 4,551 & 0.26674 & 0.09349 & 0.048 & 0.557 \\
\hline \multicolumn{6}{|c|}{ Date } \\
\hline Date & 4,551 & 22062.9 & 35.6531 & 21995 & 22124 \\
\hline afterSHO & 4,552 & 0.56305 & 0.49606 & 0 & 1 \\
\hline \multicolumn{6}{|c|}{ COVID } \\
\hline New Case / 1k (t-1) & 4,551 & 0.1216 & 0.16573 & 0 & 1.007 \\
\hline Death Rt (t-1) & 4,551 & 0.01737 & 0.00817 & 0.0032 & 0.0458 \\
\hline Exposure / 1k ( $\mathrm{t}-1)$ & 4,551 & 11.5198 & 12.1186 & 0.48 & 52.03 \\
\hline Days Decr. (t-1) & 4,551 & 3.57064 & 6.49126 & 0 & 44 \\
\hline \multicolumn{6}{|c|}{ ECON } \\
\hline Unemploy Rt (t-1) & 4,551 & 0.21547 & 0.07449 & 0.081 & 0.444 \\
\hline Median Inc. (t-1) & 4,551 & 62176.3 & 10649.5 & 44445 & 84342 \\
\hline Emp Density (t-1) & 4,551 & 511.443 & 2569.62 & 1 & 16044 \\
\hline \multicolumn{6}{|c|}{ Demographics } \\
\hline$\% 60+(\mathrm{t}-1)$ & 4,551 & 0.22194 & 0.02325 & 0.17 & 0.27 \\
\hline \% African Am. (t-1) & 4,551 & 0.12306 & 0.11018 & 0.004 & 0.461 \\
\hline$\%$ Hispanic Am. (t-1) & 4,551 & 0.10943 & 0.08692 & 0.015 & 0.392 \\
\hline$\%$ male $(\mathrm{t}-1)$ & 4,551 & 0.49291 & 0.00803 & 0.4746 & 0.5221 \\
\hline
\end{tabular}

Figure 1. Trend of WFH, COVID severity, Unemployment, March 21-July 28, 2020

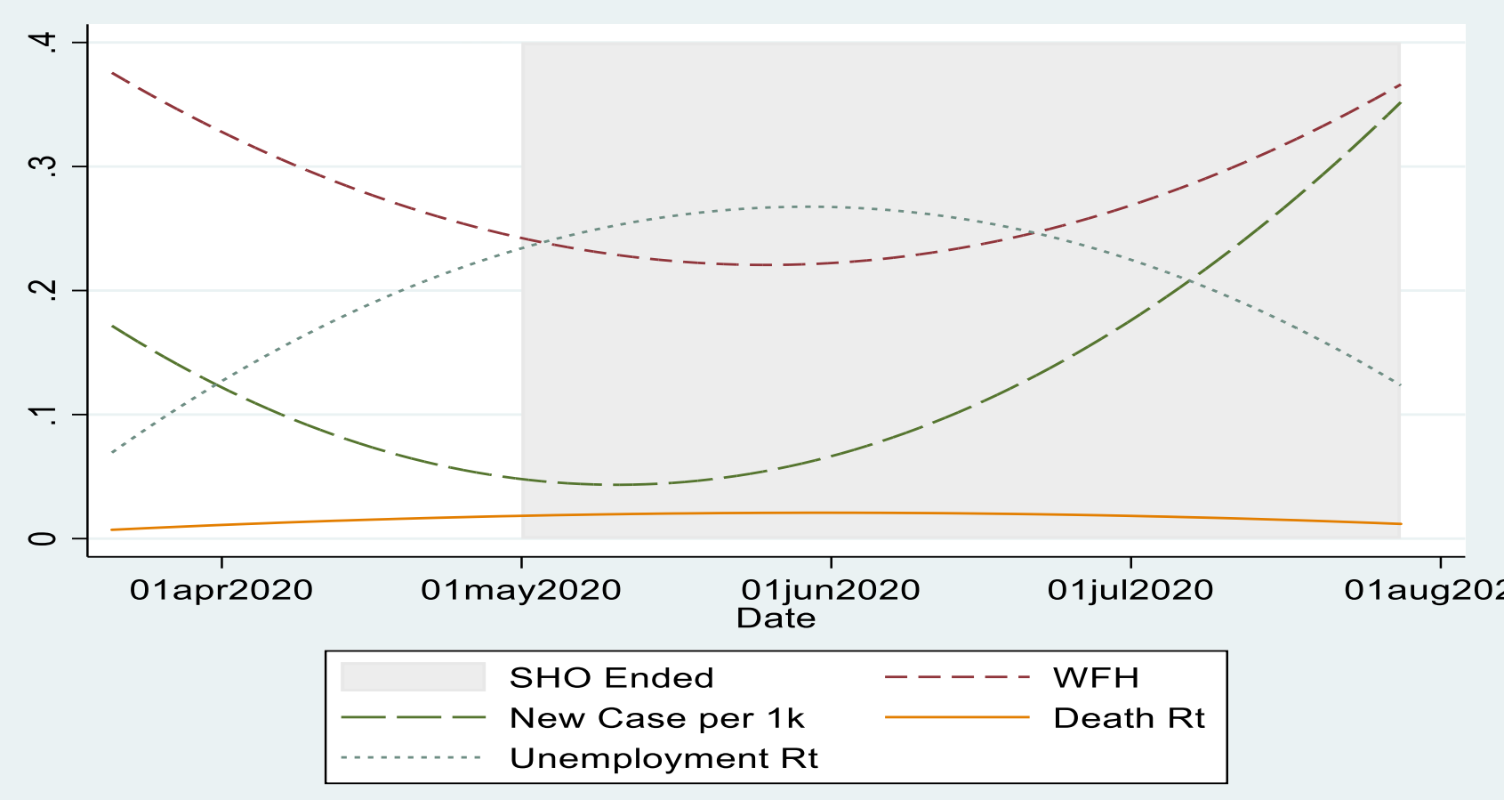


Table 3. Empirical Models for the End of SHO Effect on WFH Rates

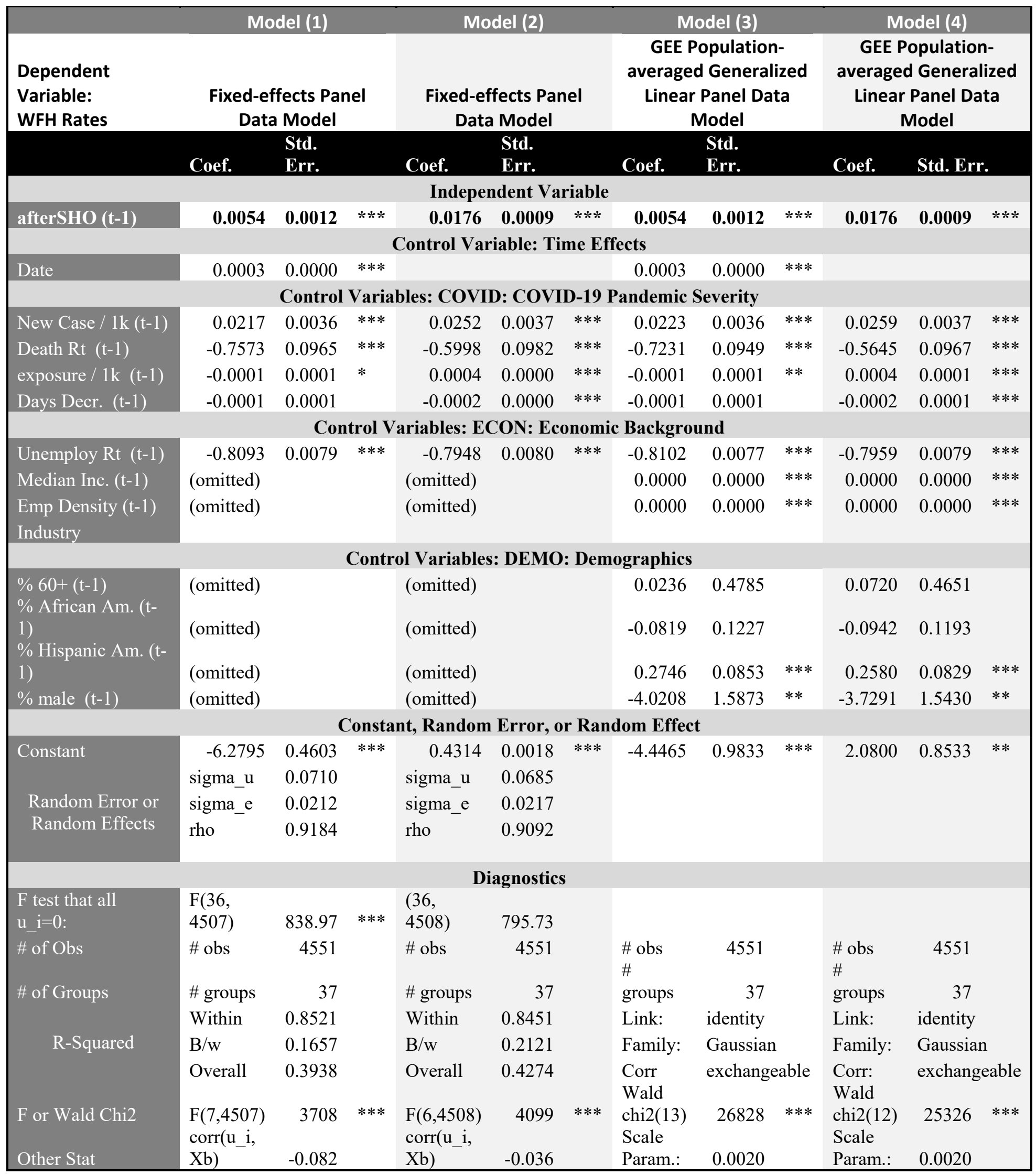


Figure 2. Marginal Effect of the End of SHO on WFH based on Model (4)

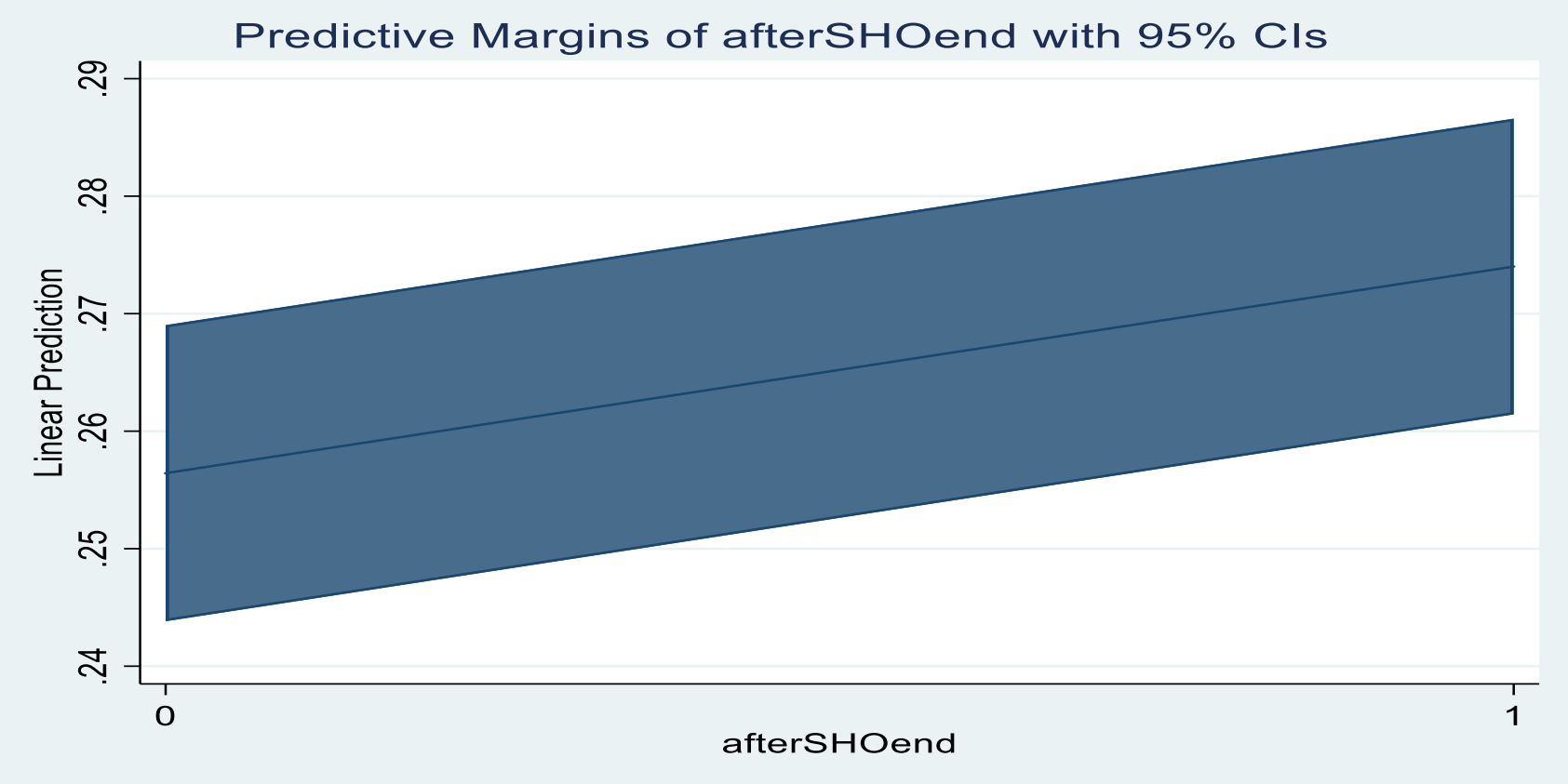


Table 4. WFH Effects on Small Business Performance with Financial Assistance, Multilevel Mixed-effects Models (12)-(18)

\begin{tabular}{|c|c|c|c|c|c|c|c|c|c|c|c|c|c|c|c|c|c|c|c|c|c|}
\hline & \multicolumn{3}{|c|}{ No Cash FLow } & \multicolumn{3}{|c|}{$\begin{array}{c}\text { Cash Flow foe 1-4 } \\
\text { Weeks }\end{array}$} & \multicolumn{3}{|c|}{$\begin{array}{l}\text { Cash Flow for 1-2 } \\
\text { Months }\end{array}$} & \multicolumn{3}{|c|}{$\begin{array}{c}\text { Cash Flow for } 3+ \\
\text { Months }\end{array}$} & \multicolumn{3}{|c|}{$\begin{array}{l}\text { Operating } \\
\text { Revenue }\end{array}$} & \multicolumn{3}{|c|}{$\begin{array}{l}\text { Temporary } \\
\text { Closure }\end{array}$} & \multicolumn{3}{|c|}{$\begin{array}{l}\text { Disruptino in } \\
\text { Supply Chain }\end{array}$} \\
\hline & \multicolumn{3}{|c|}{ Model (12) } & \multicolumn{3}{|c|}{ Model (13) } & \multicolumn{3}{|c|}{ Model (14) } & \multicolumn{3}{|c|}{ Model (15) } & \multicolumn{3}{|c|}{ Model (16) } & \multicolumn{3}{|c|}{ Model (17) } & \multicolumn{3}{|c|}{ Model (18) } \\
\hline & Coef & $\begin{array}{l}\text { St. } \\
\text { Er. }\end{array}$ & & Coef & $\begin{array}{l}\text { St. } \\
\text { Er. }\end{array}$ & & Coef & $\begin{array}{l}\text { St. } \\
\text { Er. }\end{array}$ & & Coef & $\begin{array}{l}\text { St. } \\
\text { Er. }\end{array}$ & & Coef & $\begin{array}{l}\text { St. } \\
\text { Er. }\end{array}$ & & Coef & $\begin{array}{l}\text { St. } \\
\text { Er. }\end{array}$ & & Coef & St. Er & \\
\hline \multicolumn{22}{|c|}{ WFH: Work From Home } \\
\hline WFH (t-1) & -0.01 & 0.01 & & 0.14 & 0.06 & $* *$ & 0.45 & 0.09 & $* * *$ & 0.35 & 0.08 & $* * *$ & 0.61 & 0.15 & $* * *$ & -0.75 & 0.18 & $* * *$ & -0.39 & 0.18 & $* *$ \\
\hline afterSHO (t-1) & 0.00 & 0.00 & $*$ & 0.03 & 0.00 & $\begin{array}{l}* * \\
*\end{array}$ & 0.00 & 0.01 & & 0.01 & 0.01 & $* *$ & 0.23 & 0.01 & $\begin{array}{l}* * \\
*\end{array}$ & 0.24 & 0.01 & $\begin{array}{l}* * \\
*\end{array}$ & 0.10 & $\begin{array}{r}0.0 \\
1\end{array}$ & $\begin{array}{l}* * \\
*\end{array}$ \\
\hline \multicolumn{22}{|c|}{ COVID: COVID-19 Pandemic Severity } \\
\hline & & & $* *$ & & & & - & & & & & & - & & $* *$ & & & $* *$ & & 0.1 & \\
\hline New Case / 1k (t-1) & 0.03 & 0.00 & $*$ & 0.06 & 0.04 & & 0.12 & 0.06 & $*$ & 0.09 & 0.06 & & $\begin{array}{r}0.45 \\
-\end{array}$ & 0.11 & $\begin{array}{l}* \\
* *\end{array}$ & 0.43 & 0.13 & $\begin{array}{l}* \\
* *\end{array}$ & 0.29 & $\begin{array}{r}3 \\
1.1\end{array}$ & $\begin{array}{l}* * \\
* *\end{array}$ \\
\hline Death Rt (t-1) & 0.06 & 0.04 & & 0.79 & 0.37 & $\begin{array}{l}* * \\
* *\end{array}$ & 0.91 & 0.55 & $\begin{array}{l}* \\
* *\end{array}$ & 1.09 & 0.50 & $\begin{array}{l}* * \\
* *\end{array}$ & 9.72 & 0.97 & $\begin{array}{l}* \\
* *\end{array}$ & 8.64 & 1.14 & $*$ & 4.86 & $\begin{array}{r}4 \\
0.0\end{array}$ & $*$ \\
\hline exposure / 1k (t-1) & 0.00 & 0.00 & $* *$ & 0.00 & 0.00 & $\begin{array}{l}* \\
* *\end{array}$ & 0.00 & 0.00 & $*$ & 0.00 & 0.00 & $\begin{array}{l}* \\
* *\end{array}$ & 0.01 & 0.00 & $\begin{array}{l}* \\
* *\end{array}$ & 0.00 & 0.00 & $\begin{array}{l}* * \\
* *\end{array}$ & 0.00 & $\begin{array}{r}0 \\
0.0\end{array}$ & \\
\hline Days Decr. (t-1) & 0.00 & 0.00 & & 0.00 & 0.00 & $*$ & 0.00 & 0.00 & $*$ & 0.00 & 0.00 & $*$ & 0.00 & 0.00 & $*$ & 0.00 & 0.00 & $*$ & 0.00 & 0 & \\
\hline \multicolumn{22}{|c|}{ ECON: Economic Background } \\
\hline Unemploy Rt (t-1) & 0.01 & 0.01 & $* *$ & 0.02 & 0.06 & & 0.39 & 0.09 & $\begin{array}{l}* * \\
*\end{array}$ & 0.44 & 0.08 & $\begin{array}{l}* * \\
*\end{array}$ & 1.46 & 0.16 & $\begin{array}{l}* * \\
*\end{array}$ & 0.93 & 0.19 & $\begin{array}{l}* * \\
*\end{array}$ & 1.01 & $\begin{array}{r}0.1 \\
9 \\
0.0\end{array}$ & $\begin{array}{l}* * \\
*\end{array}$ \\
\hline Median Inc. (t-1) & 0.00 & 0.00 & $*$ & 0.00 & 0.00 & $* *$ & 0.00 & 0.00 & $* *$ & 0.00 & 0.00 & $* *$ & 0.00 & 0.00 & $* *$ & 0.00 & 0.00 & $\begin{array}{l}* * \\
* *\end{array}$ & 0.00 & $\begin{array}{r}0 \\
0.0\end{array}$ & \\
\hline Emp Density (t-1) & 0.00 & 0.00 & & 0.00 & 0.00 & $*$ & 0.00 & 0.00 & $*$ & 0.00 & 0.00 & $*$ & 0.00 & 0.00 & $*$ & 0.00 & 0.00 & $*$ & 0.00 & 0 & \\
\hline \multicolumn{22}{|c|}{ DEMO: Demographics } \\
\hline$\% 60+(t-1)$ & $\begin{array}{r}0.02 \\
-\end{array}$ & 0.02 & & $\begin{array}{r}- \\
0.43 \\
-\end{array}$ & 0.13 & $\begin{array}{l}* * \\
* \\
* *\end{array}$ & $\begin{array}{r}- \\
1.29 \\
-\end{array}$ & 0.20 & $\begin{array}{l}* * \\
* \\
* *\end{array}$ & $\begin{array}{r}- \\
1.11 \\
-\end{array}$ & 0.18 & $\begin{array}{l}* * \\
* \\
* *\end{array}$ & $\begin{array}{r}0.84 \\
-\end{array}$ & 0.35 & $\begin{array}{l}* * \\
* *\end{array}$ & 1.49 & 0.41 & $\begin{array}{l}* * \\
* \\
* *\end{array}$ & 0.51 & $\begin{array}{r}0.4 \\
2 \\
0.1\end{array}$ & \\
\hline$\%$ African Am. (t-1) & 0.01 & 0.00 & & 0.11 & 0.04 & $\begin{array}{l}* \\
* *\end{array}$ & 0.19 & 0.06 & $\begin{array}{l}* \\
* *\end{array}$ & 0.29 & 0.06 & $\begin{array}{l}* \\
* *\end{array}$ & $\begin{array}{r}0.32 \\
-\end{array}$ & 0.11 & $\begin{array}{l}* \\
* *\end{array}$ & 0.39 & 0.12 & $\begin{array}{l}* \\
* *\end{array}$ & 0.26 & $\begin{array}{r}3 \\
0.0\end{array}$ & $* *$ \\
\hline$\%$ male $(t-1)$ & 0.06 & 0.08 & & 4.15 & 0.72 & $*$ & 6.94 & 1.06 & $*$ & 6.00 & 0.98 & $*$ & 3.81 & 1.88 & $* *$ & 2.38 & 2.20 & & 4.37 & 2 & $* *$ \\
\hline \multicolumn{22}{|c|}{ FIN: Business Finanical Assistance } \\
\hline Fin_PPP & 0.00 & 0.00 & & 0.01 & 0.01 & & 0.06 & 0.01 & $\begin{array}{l}* * \\
*\end{array}$ & 0.06 & 0.01 & $\begin{array}{l}* * \\
*\end{array}$ & 0.14 & 0.02 & $\begin{array}{l}* * \\
*\end{array}$ & $0.12^{-}$ & 0.02 & $\begin{array}{l}* * \\
*\end{array}$ & 0.08 & $\begin{array}{r}0.0 \\
2\end{array}$ & $\begin{array}{l}* * \\
*\end{array}$ \\
\hline
\end{tabular}




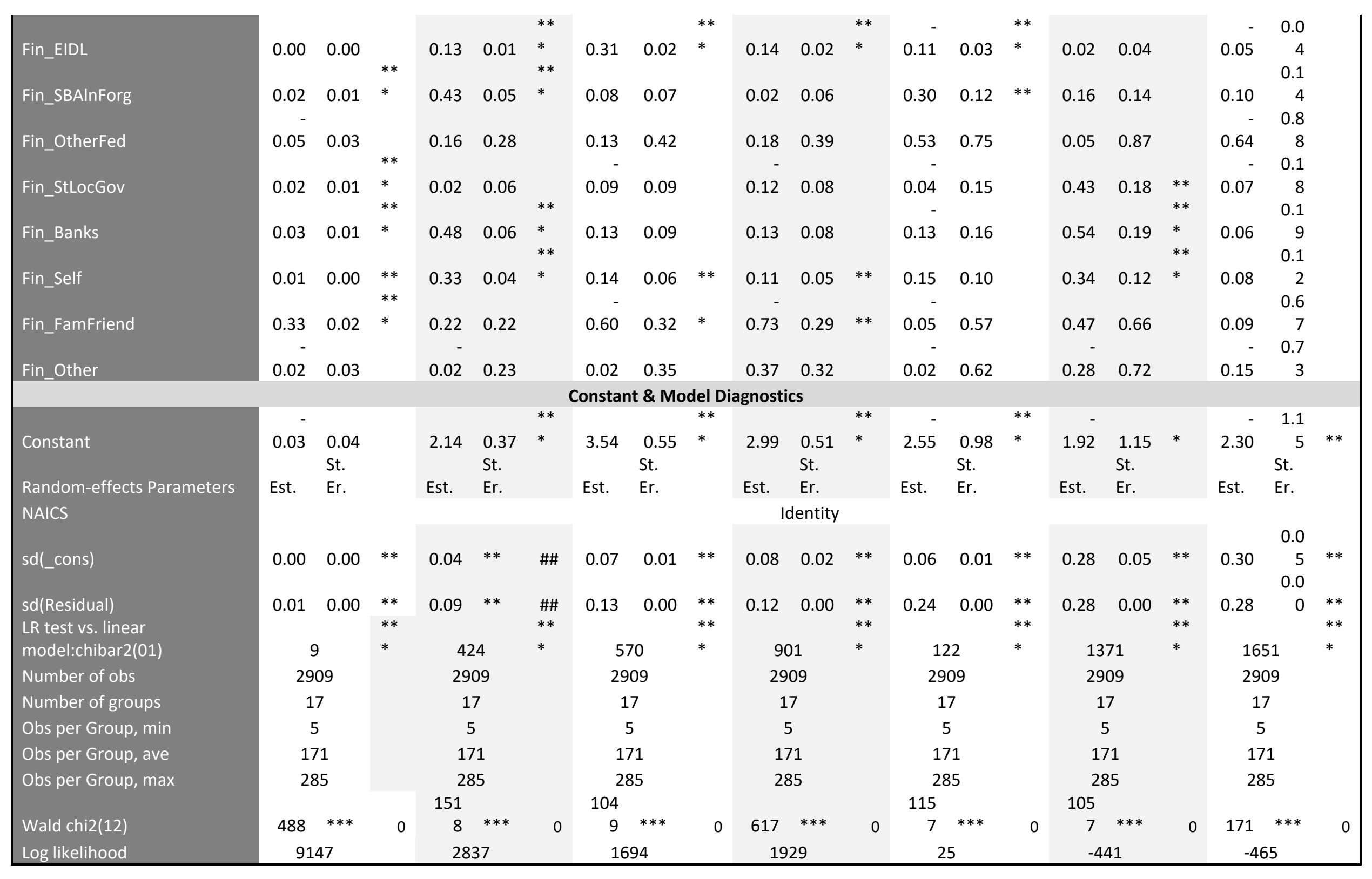




\section{Figure 3 WFH Rate Effects on Small Business' Cash Flow, Based on Models (12)-(15)}

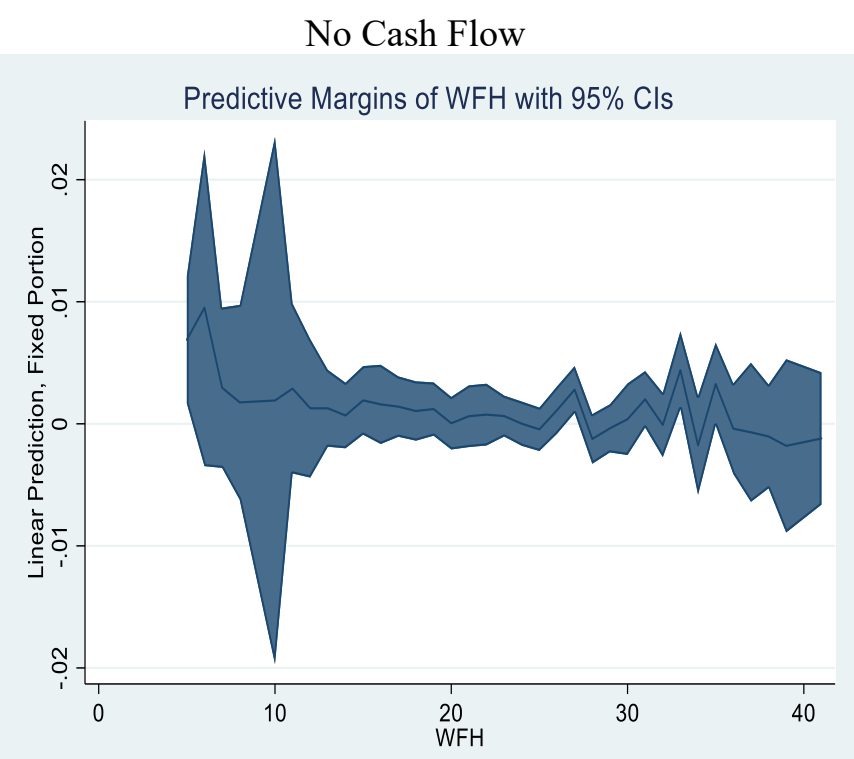

Cash Flow for 1-2 Months

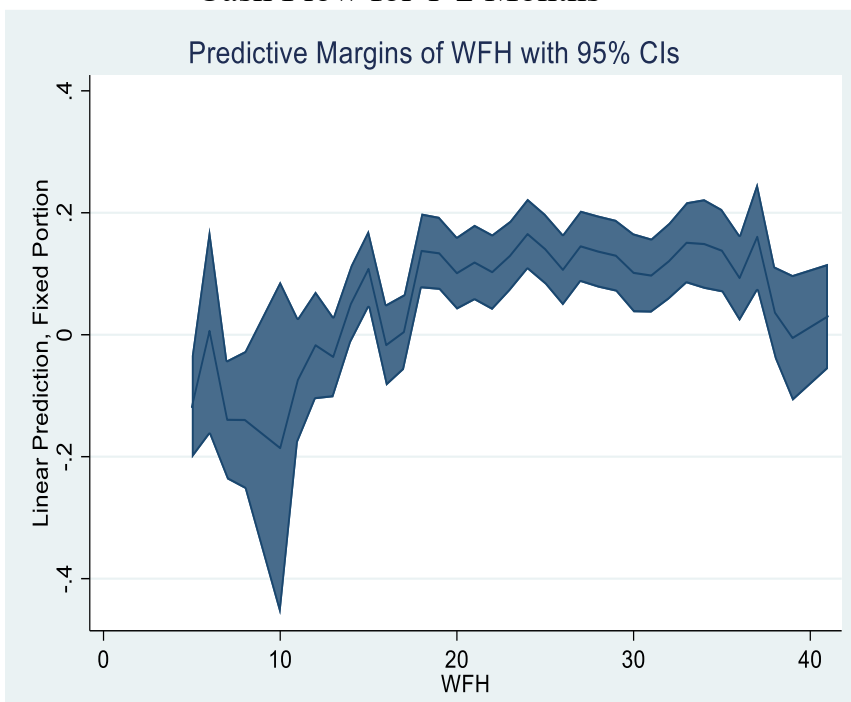

Cash Flow for 1-4 Weeks

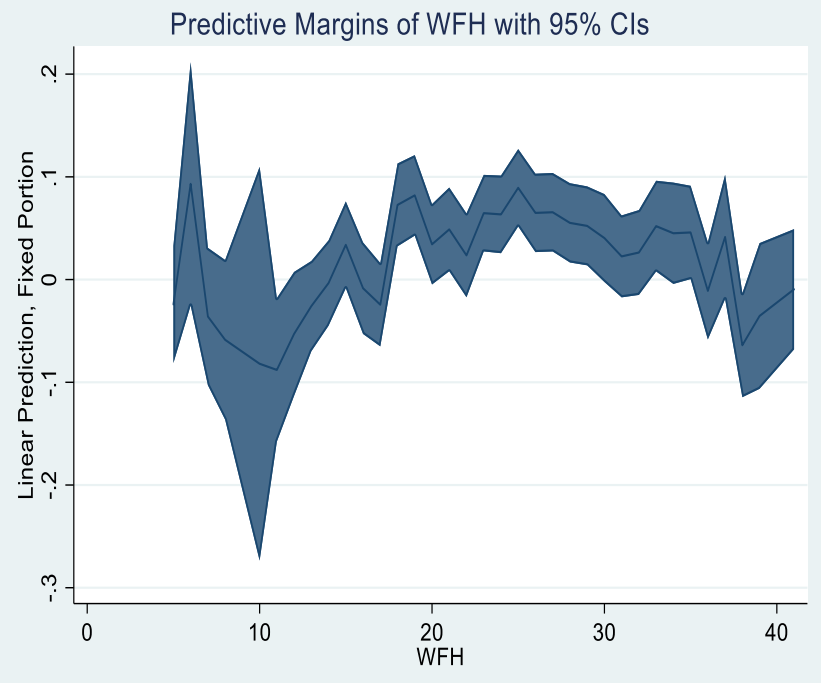

Cash Flow for 1-4 Weeks

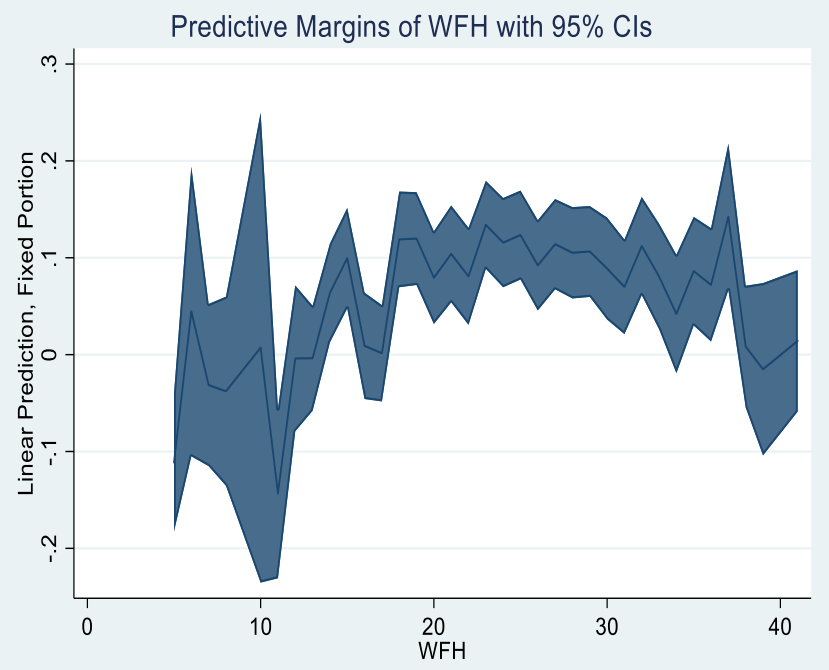

Note: This graph omitted observations for WFH rate below $3 \%$ and above $50 \%$ (i.e., omitting two tails at $2 \%$ and $51-56 \%$ ) because those observation only represent $0.7 \%$ of the observations, but have a much larger and more dramatic effect from WFH rates. Presenting those in the graph will visually inflate the WFH effects. 
Figure 4. WFH Effects on Small Business' Operating Revenue Increase, Based on Model (16)

For WFH Rate between 3-50\% (99.3\% of observation)

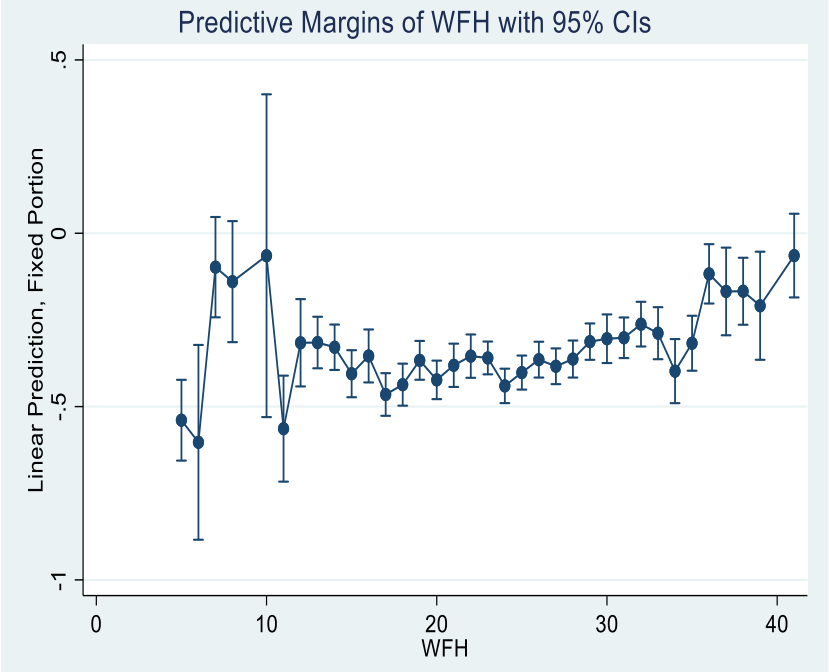

For All WFH Rates (2-56\%)

Predictive Margins of WFH with $95 \% \mathrm{Cls}$

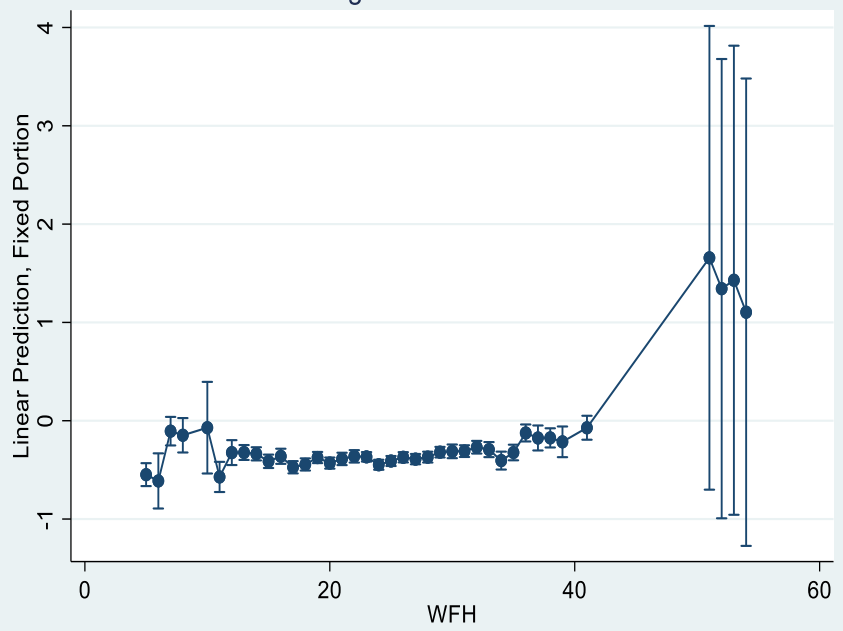

Figure 5 WFH Rate Effects on Small Business' Temporary Closure, Based on Model (17)

For WFH Rate between 3-50\% (99.3\% of observation)

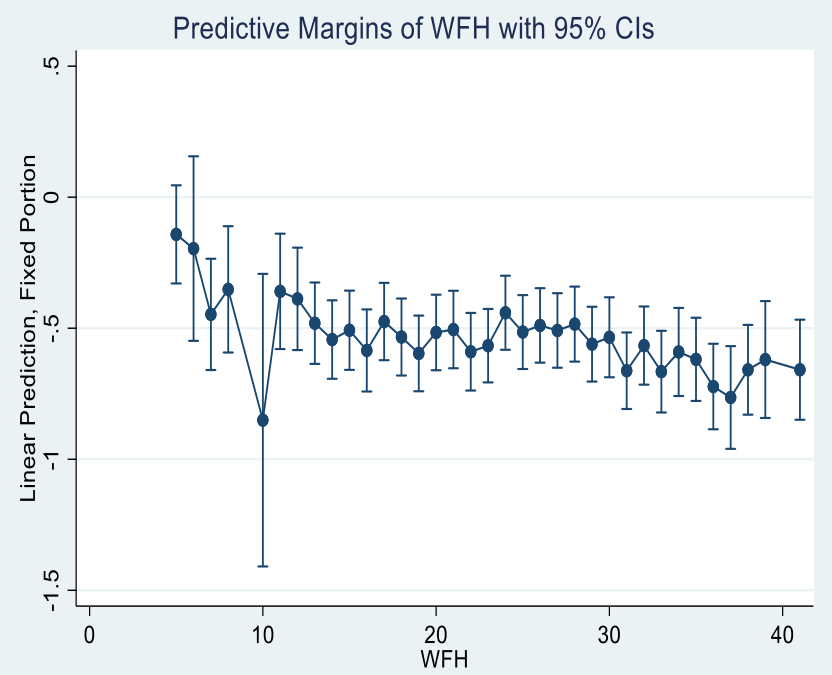

For All WFH Rates (2-56\%)

Predictive Margins of WFH with $95 \% \mathrm{Cls}$

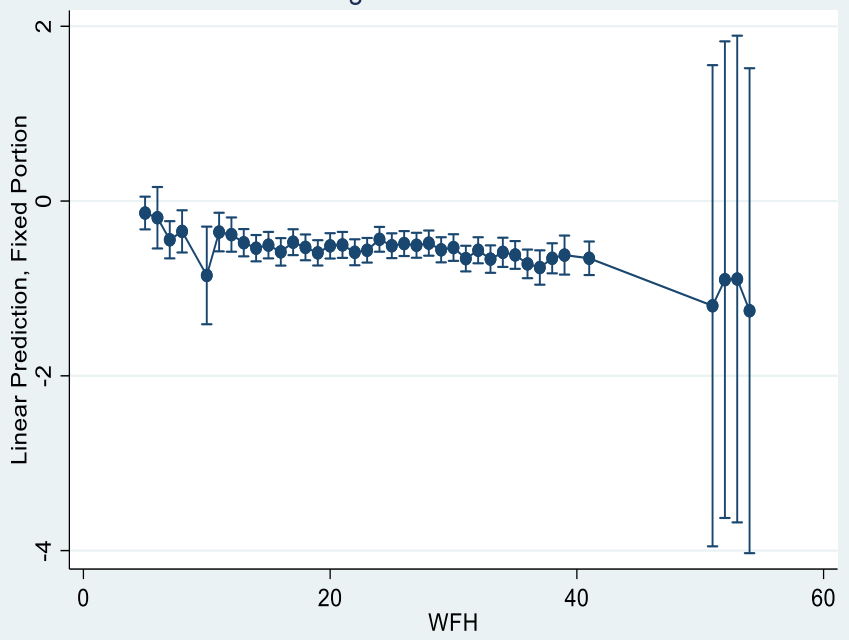


Figure 6 WFH Rate Effects on Small Business' Disruption in Supply Chain, Based on Model (18)

For WFH Rate between 3-50\% (99.3\% of observation)

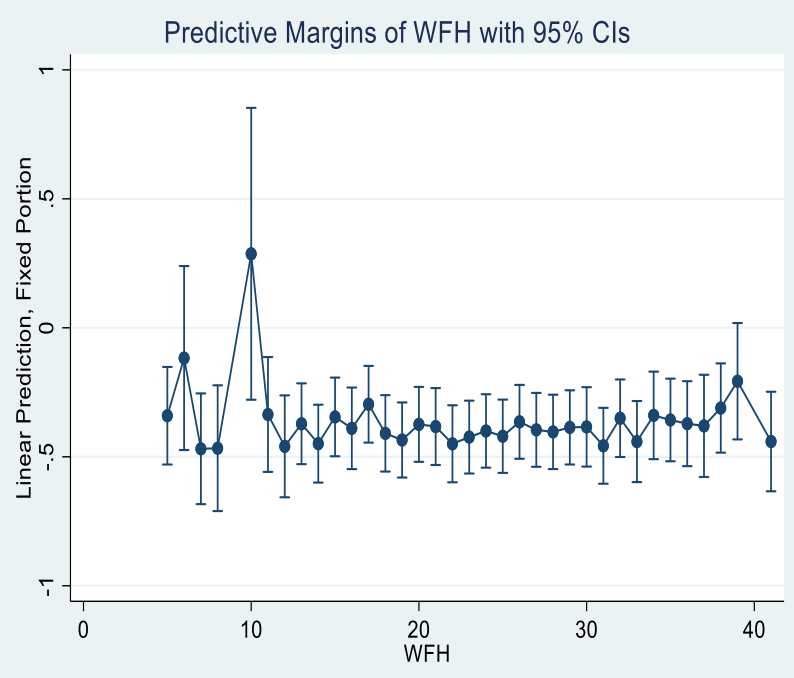

For All WFH Rates (2-56\%)

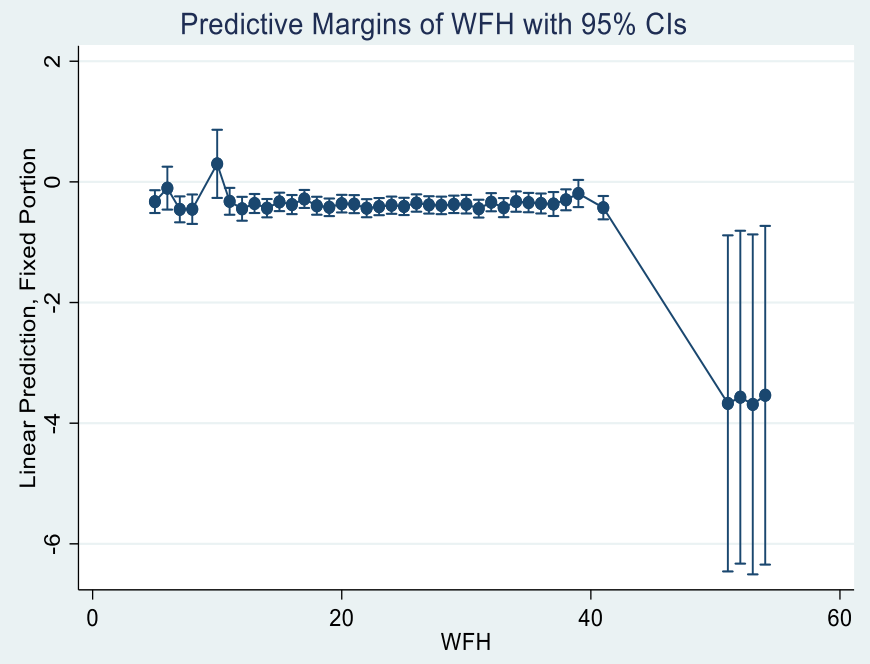




\section{Appendix}

Table A. Correlation Matrix for the Daily Data

\begin{tabular}{|r|l|r|r|r|r|r|r|r|r|r|r|r|r|r|r|}
\hline & & $\mathbf{1}$ & $\mathbf{2}$ & $\mathbf{3}$ & $\mathbf{4}$ & $\mathbf{5}$ & $\mathbf{6}$ & $\mathbf{7}$ & $\mathbf{8}$ & $\mathbf{9}$ & $\mathbf{1 0}$ & $\mathbf{1 1}$ & $\mathbf{1 2}$ & $\mathbf{1 3}$ & $\mathbf{1 4}$ \\
\hline $\mathbf{1}$ & WFH & 1.00 & & & & & & & & & & & & & \\
\hline $\mathbf{2}$ & Date & 0.06 & 1.00 & & & & & & & & & & & & \\
\hline $\mathbf{3}$ & afterSHO & -0.06 & 0.79 & 1.00 & & & & & & & & & & & \\
\hline $\mathbf{4}$ & New Case / 1k (t-1) & 0.35 & 0.37 & 0.21 & 1.00 & & & & & & & & & & \\
\hline $\mathbf{5}$ & Death Rt (t-1) & 0.01 & 0.10 & 0.04 & -0.24 & 1.00 & & & & & & & & & \\
\hline $\mathbf{6}$ & exposure / k (t-1) & 0.37 & 0.55 & 0.35 & 0.62 & 0.29 & 1.00 & & & & & & & & \\
\hline $\mathbf{7}$ & Days Decr. (t-1) & -0.10 & 0.11 & 0.10 & -0.07 & 0.28 & 0.27 & 1.00 & & & & & & & \\
\hline $\mathbf{8}$ & Unemploy Rt (t-1) & -0.65 & 0.10 & 0.14 & -0.30 & 0.44 & -0.04 & 0.24 & 1.00 & & & & & & \\
\hline $\mathbf{9}$ & Median Inc. (t-1) & 0.35 & -0.02 & -0.15 & -0.07 & 0.10 & 0.17 & 0.09 & 0.00 & 1.00 & & & & & \\
\hline $\mathbf{1 0}$ & Emp Density (t-1) & 0.48 & 0.00 & -0.03 & 0.05 & 0.06 & 0.19 & -0.04 & -0.07 & 0.33 & 1.00 & & & & \\
\hline $\mathbf{1 1}$ & \% 60+ (t-1) & -0.21 & 0.00 & -0.06 & -0.11 & 0.03 & -0.16 & 0.10 & 0.02 & -0.35 & -0.37 & 1.00 & & & \\
\hline $\mathbf{1 2}$ & \% African Am. (t- & & & & & & & & & & & & & & \\
\hline $\mathbf{1 3}$ & \% Hispanic Am. (t- & 0.26 & 0.02 & 0.04 & 0.26 & 0.12 & 0.34 & -0.07 & -0.01 & -0.01 & 0.51 & -0.35 & 1.00 & \\
\hline $\mathbf{1 4}$ & \% male (t-1) & 0.22 & 0.00 & 0.00 & 0.14 & -0.03 & 0.21 & 0.03 & 0.08 & 0.18 & 0.01 & -0.35 & -0.09 & 1 & \\
\hline
\end{tabular}

Figure A. Trend of WFH, COVID severity, Unemployment by Date and State
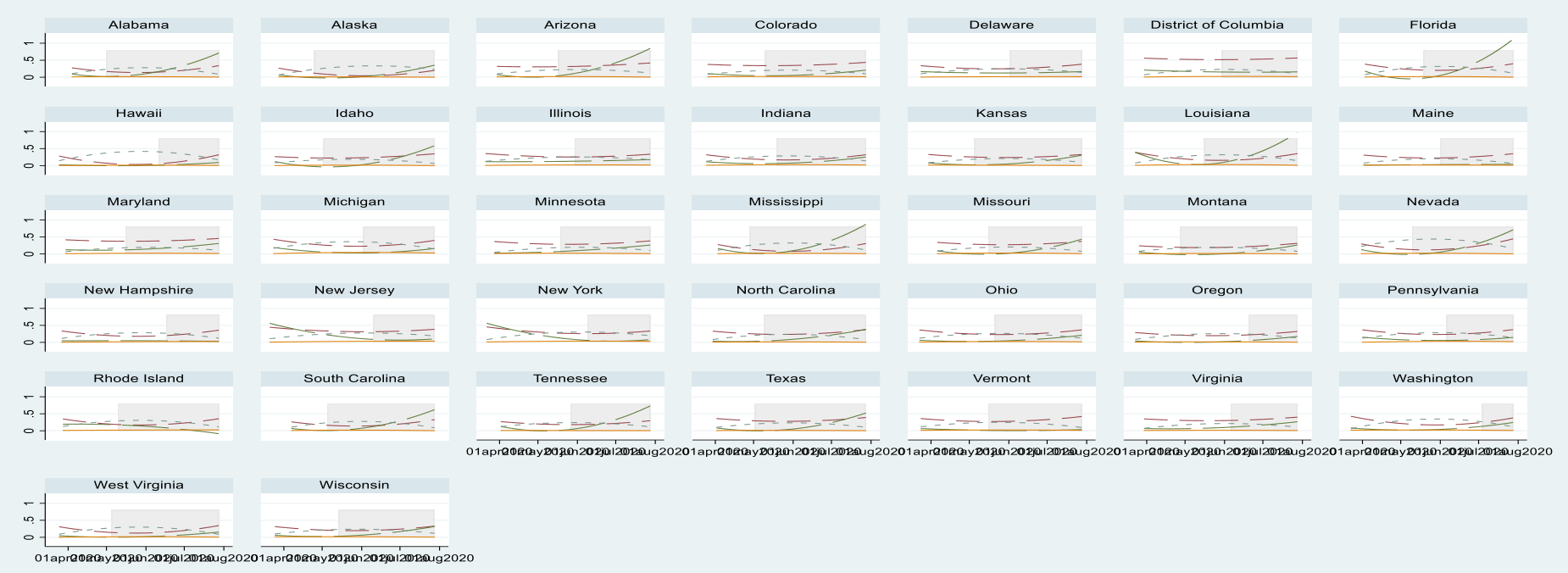

\section{Date}

\begin{tabular}{|c|c|c|}
\hline--- & $\begin{array}{l}\text { SHO Ended } \\
\text { New Case per } 1 \mathrm{k} \\
\text { Unemployment Rt }\end{array}$ & $\begin{array}{ll}----- & \text { WFH } \\
& \text { Death Rt }\end{array}$ \\
\hline
\end{tabular}


Table B. Summary Statistics of the Weekly Data

\begin{tabular}{|c|c|c|c|c|c|}
\hline Variable & Obs & Mean & Std. Dev. & Min & Max \\
\hline \multicolumn{6}{|c|}{ WFH: Work From Home } \\
\hline WFH & 687 & 0.270 & 0.092 & 0.048 & 0.557 \\
\hline WFH (t-1) & 687 & 0.268 & 0.092 & 0.048 & 0.557 \\
\hline \multicolumn{6}{|c|}{ Business: Business Performance Measures } \\
\hline cashFlow0 & 333 & 0.021 & 0.027 & 0.000 & 0.119 \\
\hline cashFlow4w & 333 & 0.312 & 0.087 & 0.000 & 0.526 \\
\hline cashFlow2m & 333 & 0.291 & 0.041 & 0.143 & 0.426 \\
\hline cashFlow $3 \mathrm{~m}+$ & 333 & 0.228 & 0.054 & 0.000 & 0.415 \\
\hline Opr Rev & 333 & -0.400 & 0.180 & -0.811 & -0.052 \\
\hline Tenp Closure & 333 & -0.464 & 0.219 & -0.863 & 0.290 \\
\hline Disrpt. Sup Chn & 333 & -0.239 & 0.120 & -0.624 & 0.078 \\
\hline \multicolumn{6}{|c|}{ Time Effects } \\
\hline afterSHO & 687 & 0.568 & 0.495 & 0.000 & 1.000 \\
\hline \multicolumn{6}{|c|}{ COVID: COVID-19 Pandemic Severity } \\
\hline New Case / 1k (t-1) & 687 & 0.115 & 0.158 & 0.000 & 1.007 \\
\hline Death Rt (t-1) & 687 & 0.017 & 0.008 & 0.004 & 0.045 \\
\hline Exposure / 1k (t-1) & 687 & 10.66 & 11.71 & 0.480 & 52.03 \\
\hline Days Decr. (t-1) & 687 & 3.267 & 6.120 & 0.000 & 44.000 \\
\hline \multicolumn{6}{|c|}{ ECON: Economic Background } \\
\hline Unemploy Rt (t-1) & 687 & 0.211 & 0.074 & 0.081 & 0.444 \\
\hline Median Inc. (t-1) & 687 & 62171 & 10659 & 44445 & 84342 \\
\hline Emp Density (t-1) & 687 & 506 & 2553 & 1 & 16044 \\
\hline \multicolumn{6}{|c|}{ DEMO: Demographics } \\
\hline$\% 60+(\mathrm{t}-1)$ & 687 & 0.222 & 0.023 & 0.170 & 0.270 \\
\hline$\%$ African Am. (t-1) & 687 & 0.123 & 0.110 & 0.004 & 0.461 \\
\hline \% Hispanic Am. (t-1) & 687 & 0.109 & 0.087 & 0.015 & 0.392 \\
\hline$\%$ male $(\mathrm{t}-1)$ & 687 & 0.493 & 0.008 & 0.475 & 0.522 \\
\hline \multicolumn{6}{|c|}{ FIN: Business Financial Assistance } \\
\hline Fin_PPP & 333 & 0.743 & 0.047 & 0.551 & 0.879 \\
\hline Fin_EIDL & 333 & 0.276 & 0.047 & 0.125 & 0.424 \\
\hline Fin_SBAlnForg & 333 & 0.087 & 0.042 & 0.000 & 0.203 \\
\hline Fin_OtherFed & 333 & 0.009 & 0.013 & 0.000 & 0.047 \\
\hline Fin_StLocGov & 333 & 0.045 & 0.061 & 0.000 & 0.317 \\
\hline Fin_Banks & 333 & 0.063 & 0.038 & 0.000 & 0.158 \\
\hline Fin_Self & 333 & 0.096 & 0.042 & 0.000 & 0.193 \\
\hline Fin_FamFriend & 333 & 0.022 & 0.023 & 0.000 & 0.143 \\
\hline Fin_Other & 333 & 0.020 & 0.021 & 0.000 & 0.104 \\
\hline
\end{tabular}


Table C. WFH Effects on Small Business Performance, Multilevel Mixed-effects Models

\begin{tabular}{|c|c|c|c|c|c|c|c|c|c|c|c|c|c|c|c|c|c|c|c|c|c|}
\hline $\begin{array}{l}\text { Dependent } \\
\text { Variables: }\end{array}$ & \multicolumn{3}{|c|}{ No Cash Flow } & \multicolumn{3}{|c|}{$\begin{array}{c}\text { Cash Flow foe 1-4 } \\
\text { Weeks }\end{array}$} & \multicolumn{3}{|c|}{$\begin{array}{c}\text { Cash Flow for 1-2 } \\
\text { Months } \\
\end{array}$} & \multicolumn{3}{|c|}{$\begin{array}{c}\text { Cash Flow for 3+ } \\
\text { Months }\end{array}$} & \multicolumn{3}{|c|}{$\begin{array}{c}\text { Increase } \\
\text { Operating } \\
\text { Revenue } \\
\end{array}$} & \multicolumn{3}{|c|}{$\begin{array}{c}\text { Temporary } \\
\text { Closure }\end{array}$} & \multicolumn{3}{|c|}{$\begin{array}{l}\text { Disruption in } \\
\text { Supply Chain }\end{array}$} \\
\hline & \multicolumn{3}{|c|}{ Model (5) } & \multicolumn{3}{|c|}{ Model (6) } & \multicolumn{3}{|c|}{ Model (7) } & \multicolumn{3}{|c|}{ Model 8) } & \multicolumn{3}{|c|}{ Model (9) } & \multicolumn{3}{|c|}{ Model (10) } & \multicolumn{3}{|c|}{ Model (11) } \\
\hline & \multicolumn{3}{|c|}{ f. Er. } & \multicolumn{3}{|c|}{ St. } & \multicolumn{3}{|c|}{$\begin{array}{ll} & \text { St. } \\
\text { ef. } & \text { Er. }\end{array}$} & \multicolumn{3}{|c|}{$\begin{array}{ll} & \text { St. } \\
\text { Coef. } & \text { Er. }\end{array}$} & \multicolumn{3}{|c|}{$\begin{array}{l}\text { St. } \\
\text { Er. }\end{array}$} & \multicolumn{3}{|c|}{ St. } & \multicolumn{3}{|c|}{ St. } \\
\hline \multicolumn{22}{|c|}{ Independent Variable: WFH: Work From Home } \\
\hline WFH (t-1) & -0.01 & 0.01 & & 0.18 & 0.06 & $* * *$ & 0.54 & 0.09 & $* * *$ & 0.38 & 0.08 & $* * *$ & 0.59 & 0.16 & $* * *$ & -0.94 & 0.18 & $* * *$ & -0.50 & 0.18 & $* * *$ \\
\hline \multicolumn{22}{|c|}{ Control Variable: Time Effects } \\
\hline afterSHO (t-1) & 0.00 & 0.00 & $* * *$ & -0.04 & 0.00 & $* * *$ & -0.01 & 0.01 & $* *$ & 0.00 & 0.01 & & 0.23 & 0.01 & $* * *$ & -0.23 & 0.01 & $* * *$ & -0.10 & 0.01 & $* * *$ \\
\hline \multicolumn{22}{|c|}{ Control Variables: COVID: COVID-19 Pandemic Severity } \\
\hline $\begin{array}{l}\text { New Case / 1k (t- } \\
\text { 1) }\end{array}$ & 0.02 & 0.00 & $* * *$ & 0.06 & 0.05 & & -0.16 & 0.06 & $* *$ & 0.02 & 0.06 & & $\begin{array}{r}-0.26 \\
-\end{array}$ & 0.11 & $* *$ & 0.22 & 0.13 & $*$ & 0.17 & 0.13 & \\
\hline $\begin{array}{l}\text { Death Rt (t-1) } \\
\text { exposure / 1k (t- }\end{array}$ & 0.09 & 0.05 & $*$ & 1.93 & 0.42 & $* * *$ & 2.03 & 0.59 & $* * *$ & 1.74 & 0.53 & $* * *$ & 10.32 & 1.01 & $* * *$ & 10.45 & 1.18 & $* * *$ & 5.20 & 1.17 & $* * *$ \\
\hline & 0.00 & 0.00 & $* * *$ & 0.00 & 0.00 & $* * *$ & 0.00 & 0.00 & $* * *$ & 0.00 & 0.00 & $* * *$ & 0.01 & 0.00 & $* * *$ & 0.00 & 0.00 & $* * *$ & 0.00 & 0.00 & \\
\hline Days Decr. (t-1) & 0.00 & 0.00 & & 0.00 & 0.00 & $* * *$ & 0.00 & 0.00 & $* * *$ & 0.00 & 0.00 & $* * *$ & 0.00 & 0.00 & $* * *$ & 0.00 & 0.00 & $*$ & 0.00 & 0.00 & \\
\hline \multicolumn{22}{|c|}{ Control Variables: ECON: Economic Background } \\
\hline $\begin{array}{l}\text { Unemploy Rt（t- } \\
\text { 1) }\end{array}$ & -0.01 & 0.01 & $*$ & 0.04 & 0.07 & & 0.43 & 0.10 & $* * *$ & 0.46 & 0.09 & $* * *$ & 1.50 & 0.17 & $* * *$ & -1.17 & 0.19 & $* * *$ & -1.14 & 0.19 & $* * *$ \\
\hline Median Inc. (t-1) & 0.00 & 0.00 & & 0.00 & 0.00 & & 0.00 & 0.00 & $*$ & 0.00 & 0.00 & $* * *$ & 0.00 & 0.00 & $* * *$ & 0.00 & 0.00 & $* * *$ & 0.00 & 0.00 & \\
\hline Emp Density (t-1) & 0.00 & 0.00 & & 0.00 & 0.00 & $* * *$ & 0.00 & 0.00 & $* * *$ & 0.00 & 0.00 & $* * *$ & 0.00 & 0.00 & $* * *$ & 0.00 & 0.00 & $* * *$ & 0.00 & 0.00 & \\
\hline \multicolumn{22}{|c|}{ Control Variables: DEMO: Demographics } \\
\hline $\begin{array}{l}\% 60+(\mathrm{t}-1) \\
\% \text { African Am. (t- }\end{array}$ & 0.01 & 0.02 & & -0.69 & 0.15 & $* * *$ & -1.58 & 0.21 & $* * *$ & -1.33 & 0.18 & $* * *$ & 0.81 & 0.35 & $* *$ & 1.88 & 0.41 & $* * *$ & 0.76 & 0.41 & $*$ \\
\hline 1) Hispanic Am. & -0.01 & 0.00 & & -0.19 & 0.04 & $* * *$ & -0.26 & 0.06 & $* * *$ & -0.34 & 0.06 & $* * *$ & -0.31 & 0.11 & $* * *$ & 0.42 & 0.13 & $* * *$ & 0.32 & 0.12 & $* *$ \\
\hline$(\mathrm{t}-1)$ & 0.01 & 0.00 & $* * *$ & 0.42 & 0.03 & $* * *$ & 0.42 & 0.04 & $* * *$ & 0.27 & 0.04 & $* * *$ & -0.81 & 0.07 & $* * *$ & 0.77 & 0.09 & $* * *$ & 0.24 & 0.09 & $* * *$ \\
\hline$\%$ male $(\mathrm{t}-1)$ & -0.04 & 0.09 & & -7.25 & 0.78 & $* * *$ & 10.30 & 1.11 & $* * *$ & -7.98 & 0.99 & $* * *$ & 4.77 & 1.89 & $* *$ & 2.09 & 2.20 & & 5.64 & 2.19 & $* * *$ \\
\hline & & & & & & & & onsta & $\alpha$ & del Dia & gnosti & & & & & & & & & & \\
\hline $\begin{array}{l}\text { Constant } \\
\text { Random-effects } \\
\text { Parameters: }\end{array}$ & $\begin{array}{l}0.02 \\
\text { Est. }\end{array}$ & $\begin{array}{l}0.04 \\
\text { St. } \\
\text { Er. }\end{array}$ & & $\begin{array}{l}3.68 \\
\text { Est. }\end{array}$ & $\begin{array}{l}0.40 \\
\text { St. } \\
\text { Er. }\end{array}$ & $* * *$ & $\begin{array}{l}5.23 \\
\text { Est. }\end{array}$ & $\begin{array}{l}0.58 \\
\text { St. } \\
\text { Er. }\end{array}$ & $* * *$ & $\begin{array}{l}4.02 \\
\text { Est. }\end{array}$ & $\begin{array}{l}0.51 \\
\text { St. } \\
\text { Er. }\end{array}$ & $* * *$ & $\begin{array}{l}-3.10 \\
\text { Est. }\end{array}$ & $\begin{array}{l}0.98 \\
\text { St. } \\
\text { Er. }\end{array}$ & $* * *$ & $\begin{array}{l}-1.95 \\
\text { Est. }\end{array}$ & $\begin{array}{l}1.14 \\
\text { St. } \\
\text { Er. }\end{array}$ & $*$ & $\begin{array}{l}-3.00 \\
\text { Est. }\end{array}$ & $\begin{array}{l}1.14 \\
\text { St. } \\
\text { Er. }\end{array}$ & $* * *$ \\
\hline NAICS industry & & & & & & & & & & & dentit & & & & & & & & & & \\
\hline
\end{tabular}




\begin{tabular}{|c|c|c|c|c|c|c|c|c|c|c|c|c|c|c|c|c|c|c|c|c|c|}
\hline $\operatorname{sd}($ cons $)$ & 0.00 & 0.00 & $* *$ & 0.07 & 0.01 & $* *$ & 0.10 & 0.02 & $* *$ & 0.08 & 0.02 & $* *$ & 0.06 & 0.02 & $* *$ & 0.28 & 0.05 & $* *$ & 0.28 & 0.05 & $* *$ \\
\hline sd(Residual) & 0.01 & 0.00 & $* *$ & 0.10 & 0.00 & $* *$ & 0.14 & 0.00 & $* *$ & 0.13 & 0.00 & $* *$ & 0.24 & 0.00 & $* *$ & 0.28 & 0.00 & $* *$ & 0.28 & 0.00 & $* *$ \\
\hline model:chibar2(01) & 27.2 & & $* * *$ & 694 & & $* * *$ & 779. & & $* * *$ & 802 & & $* * *$ & 118. & & $* * *$ & 1404 & & $* * *$ & 204 & .56 & $* * *$ \\
\hline Number of obs & 2909 & & & 2909 & & & 2909 & & & 2909 & & & 2909 & & & 2909 & & & 2909 & & \\
\hline Number of groups & 17 & & & 17 & & & 17 & & & 17 & & & 17 & & & 17 & & & 17 & & \\
\hline $\min$ & 5 & & & 5 & & & 5 & & & 5 & & & 5 & & & 5 & & & 5 & & \\
\hline $\begin{array}{l}\text { Obs per Group, } \\
\text { Obs }\end{array}$ & 171 & & & 171 & & & 171 & & & 171 & & & 171 & & & 171 & & & 171 & & \\
\hline $\max$ & 285 & & & 285 & & & 285 & & & 285 & & & 285 & & & 285 & & & 285 & & \\
\hline Wald chi2(12) & 124 & $* * *$ & 0 & 726 & $* * *$ & 0 & 597 & $* * *$ & 0 & 441 & $* * *$ & 0 & 1014 & $* * *$ & 0 & 933 & $* * *$ & 0 & 155 & $* * *$ & 0 \\
\hline Log likelihood & 8983 & & & 2548 & & & 1515 & & & 1854 & & & -27 & & & -487 & & & -473 & & \\
\hline
\end{tabular}


Table D. Alternative Models for the End of SHO Effect on WFH

\begin{tabular}{|c|c|c|c|c|c|c|c|c|c|c|c|c|}
\hline & \multicolumn{3}{|c|}{ Model (19) } & \multicolumn{3}{|c|}{ Model (20) } & \multicolumn{3}{|c|}{ Model (21) } & \multicolumn{3}{|c|}{ Model (22) } \\
\hline & \multicolumn{3}{|c|}{$\begin{array}{c}\text { Fixed-effects Panel } \\
\text { Data Model }\end{array}$} & \multicolumn{3}{|c|}{$\begin{array}{l}\text { GEE Population- } \\
\text { averaged Generalized } \\
\text { Linear Panel Data } \\
\text { Model }\end{array}$} & \multicolumn{3}{|c|}{$\begin{array}{l}\text { GEE Population- } \\
\text { averaged Generalized } \\
\text { Linear Panel Data } \\
\text { Model }\end{array}$} & \multicolumn{3}{|c|}{ Multilevel Mixed-effects Model } \\
\hline & Coef. & \multicolumn{2}{|c|}{ Std. Err. } & Coef. & $\begin{array}{l}\text { Std. } \\
\text { Err. }\end{array}$ & & Coef. & \multicolumn{2}{|c|}{ Std. Err. } & \multicolumn{3}{|c|}{ Std. Err. } \\
\hline \multicolumn{13}{|c|}{ Time Effects } \\
\hline $\begin{array}{l}\text { Date } \\
\text { afterSHO } \\
\text { (t-1) }\end{array}$ & 0.030 & 0.004 & $* * *$ & 0.030 & 0.004 & $* * *$ & $\mathbf{0 . 0 0 7}$ & 0.001 & $* * *$ & 0.023 & 0.001 & $* * *$ \\
\hline \multicolumn{13}{|c|}{ COVID: COVID-19 Pandemic Severity } \\
\hline $\begin{array}{l}\text { New Case / } \\
1 \mathrm{k}(\mathrm{t}-1)\end{array}$ & 0.025 & 0.014 & * & 0.034 & 0.014 & ** & 0.060 & 0.011 & $* * *$ & 0.048 & 0.013 & $* * *$ \\
\hline $\begin{array}{l}\text { Death Rt } \\
(\mathrm{t}-1)\end{array}$ & -1.089 & 0.370 & $* * *$ & -0.607 & 0.354 & $*$ & 0.613 & 0.165 & $* * *$ & 4.154 & 0.093 & $* * *$ \\
\hline $1 \mathrm{k}(\mathrm{t}-1)$ & 0.001 & 0.000 & $* *$ & 0.001 & 0.000 & $* *$ & 0.002 & 0.000 & $* * *$ & -0.001 & 0.000 & $* * *$ \\
\hline $\begin{array}{l}\text { Days Decr. } \\
(\mathrm{t}-1)\end{array}$ & 0.000 & 0.000 & $*$ & 0.000 & 0.000 & $*$ & 0.000 & 0.000 & $* * *$ & 0.000 & 0.000 & $* *$ \\
\hline \multicolumn{13}{|c|}{ ECON: Economic Background } \\
\hline $\begin{array}{l}\text { Unemploy } \\
\text { Rt (t-1) } \\
\text { Median Inc }\end{array}$ & -0.702 & 0.031 & $* * *$ & -0.717 & 0.031 & $* * *$ & -0.743 & 0.021 & $* * *$ & -0.875 & 0.012 & $* * *$ \\
\hline $\begin{array}{l}\text { Median Inc. } \\
(\mathrm{t}-1) \\
\text { Emn }\end{array}$ & (omitted) & & & 0.000 & 0.000 & $* * *$ & 0.000 & 0.000 & $* * *$ & 0.000 & 0.000 & $* * *$ \\
\hline $\begin{array}{l}\text { Emp } \\
\text { Density (t- } \\
\text { 1) }\end{array}$ & (omitted) & & & 0.000 & 0.000 & $* * *$ & 0.000 & 0.000 & $* * *$ & 0.000 & 0.000 & $* * *$ \\
\hline Industry & & & & & & & Yes & & & & & \\
\hline \multicolumn{13}{|c|}{ DEMO: Demographics } \\
\hline $\begin{array}{l}\% \text { 60+ }(\mathrm{t}-1) \\
\% \text { African }\end{array}$ & (omitted) & & & 0.026 & 0.466 & & 0.142 & 0.125 & & 0.083 & 0.043 & $*$ \\
\hline $\begin{array}{l}\text { Am. }(\mathrm{t}-1) \\
\% \text { Hispanic }\end{array}$ & (omitted) & & & -0.123 & 0.120 & & -0.038 & 0.035 & & -0.021 & 0.013 & \\
\hline $\begin{array}{l}\text { Am. }(\mathrm{t}-1) \\
\% \text { male }(\mathrm{t}-\end{array}$ & (omitted) & & & 0.247 & 0.083 & $* * *$ & 0.211 & 0.020 & $* * *$ & 0.289 & 0.007 & $* * *$ \\
\hline 1) & (omitted) & & & -4.044 & 1.555 & $* * *$ & -0.480 & 0.564 & & -1.686 & 0.227 & $* * *$ \\
\hline \multicolumn{13}{|c|}{ Constant, Error Terms, or Random Effect } \\
\hline \multirow{7}{*}{$\begin{array}{l}\text { Constant, } \\
\text { Error } \\
\text { Terms, or } \\
\text { Random } \\
\text { Effect } \\
\\
\text { Random } \\
\text { Errors or } \\
\text { Random } \\
\text { Effects }\end{array}$} & & & & & & & & & & & & \\
\hline & 0.411 & 0.006 & $* * *$ & 2.225 & 0.859 & $* * *$ & 0.459 & 0.298 & & $\begin{array}{l}0.960 \\
\text { Random- } \\
\text { effects }\end{array}$ & 0.117 & $* * *$ \\
\hline & sigma_u & 0.070 & & & & & & & & Param. & Estimate & Std. Err. \\
\hline & sigma_e & 0.032 & & & & & & & & NAICS: & Identity & \\
\hline & & 0.828 & & & & & & & & $\operatorname{sd}(\mathrm{cons})$ & 0.001 & $0.001 * *$ \\
\hline & & & & & & & & & & sd(Resi.l) & 0.030 & $0.000 * *$ \\
\hline & & & & & & & on & & & & & \\
\hline
\end{tabular}




\begin{tabular}{|c|c|c|c|c|c|c|c|c|c|c|}
\hline $\begin{array}{l}F \text { test that } \\
\text { all } u_{i}=0 \text { : }\end{array}$ & $\begin{array}{l}F(36, \\
644)\end{array}$ & 58 & $* * *$ & & & & & $\begin{array}{l}\text { LR test } \\
\text { vs. linear } \\
\text { model: }\end{array}$ & chi2(01) & 0.070 \\
\hline \# of Obs & \# obs & 687 & & $\begin{array}{l}\text { \# obs } \\
\#\end{array}$ & 687 & $\begin{array}{l}\# \text { obs } \\
\#\end{array}$ & 2909 & \# obs & 2909 & \\
\hline \# of Groups & \# groups & 37 & & groups & 37 & groups & 414 & $\begin{array}{l}\text { \# groups } \\
\text { Obs per }\end{array}$ & 17 & \\
\hline & $\begin{array}{l}\text { R2 } \\
\text { Within }\end{array}$ & 0.68 & & Link: & identity & Link: & identity & $\begin{array}{l}\text { Group, } \\
\text { min } \\
\text { Obs per }\end{array}$ & 5 & \\
\hline R-Squared & $\mathrm{B} / \mathrm{w}$ & 0.16 & & Family: & Gaussian & Family: & Gaussian & $\begin{array}{l}\text { Group, } \\
\text { ave } \\
\text { Obs per }\end{array}$ & 171 & \\
\hline & $\begin{array}{l}\text { R2 } \\
\text { Overall }\end{array}$ & 0.33 & & Corr: & exchangeable & Corr: & exchangeable & $\begin{array}{l}\text { Group, } \\
\max \end{array}$ & 285 & \\
\hline $\begin{array}{l}\text { F or Wald } \\
\text { Chi2 }\end{array}$ & $\begin{array}{l}F(6,644) \\
\text { corr(u_i, }\end{array}$ & $\begin{array}{r}226 \\
-\end{array}$ & $* * *$ & $\begin{array}{l}\text { Wald } \\
\text { chi2(28) } \\
\text { Scale }\end{array}$ & $1479 * * *$ & $\begin{array}{l}\text { Wald } \\
\text { chi2(28) } \\
\text { Scale }\end{array}$ & $2297 \quad * * *$ & $\begin{array}{l}\text { Wald } \\
\text { chi2(12) } \\
\text { Log }\end{array}$ & 13545 & $* * *$ \\
\hline Other Stat & $\mathrm{Xb})$ & 0.057 & & Param.: & 0.002 & Param.: & 0.001 & likelih. & 6111 & \\
\hline
\end{tabular}

Models (19) and (20) followed the design of Models (2) and (4), i.e., using respectively fixed-effects models and population-averaged generalized linear panel-data models with the GEE approach. Model (21) followed Model (20), but added the industry sector fixed effects in. Model (22) adopted the two-level mixed-effects model controlling correlations at the both the state and industry sector levels. 
Table E. WFH Effects on Small Business Performance, Fixed-effect Panel Data Models

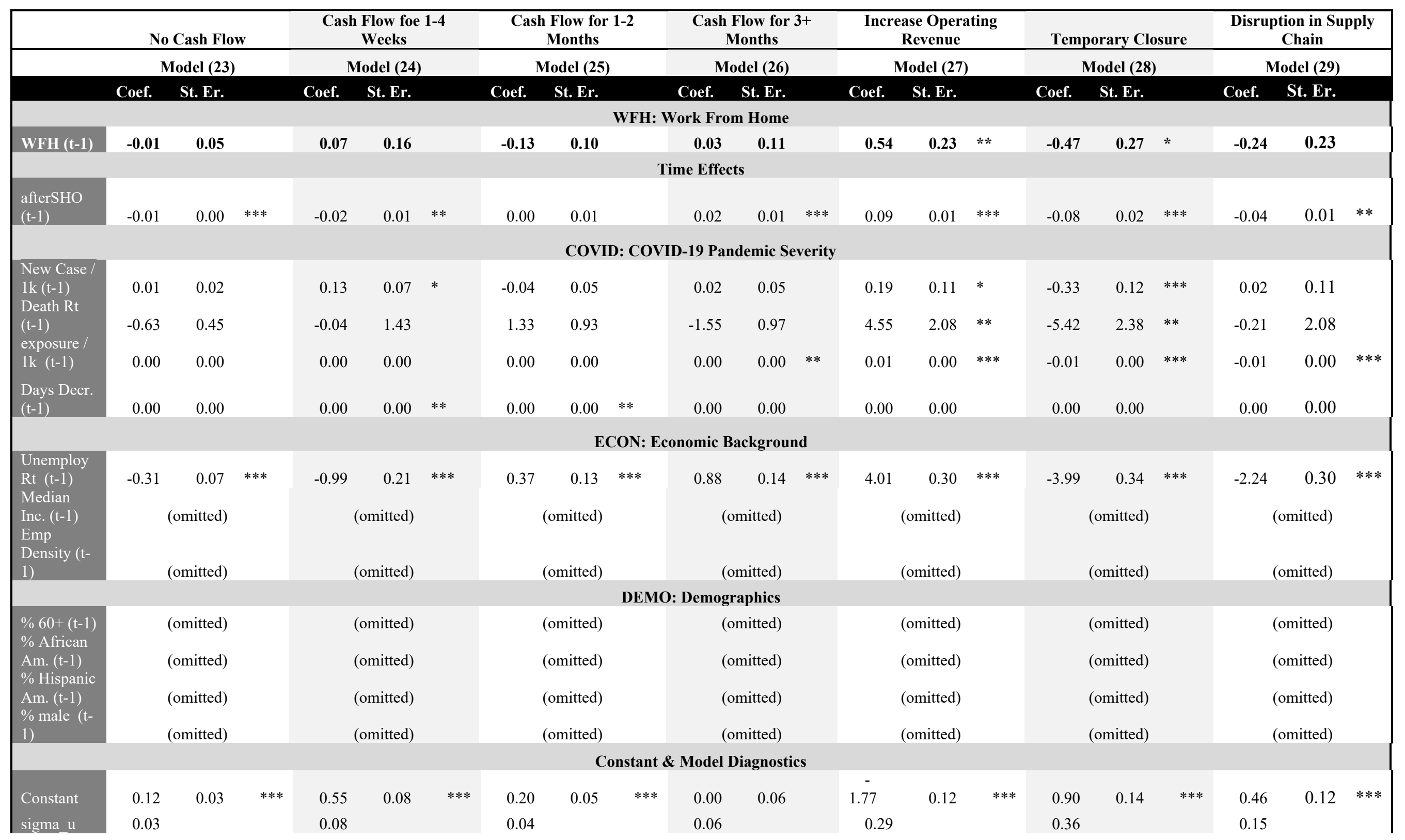




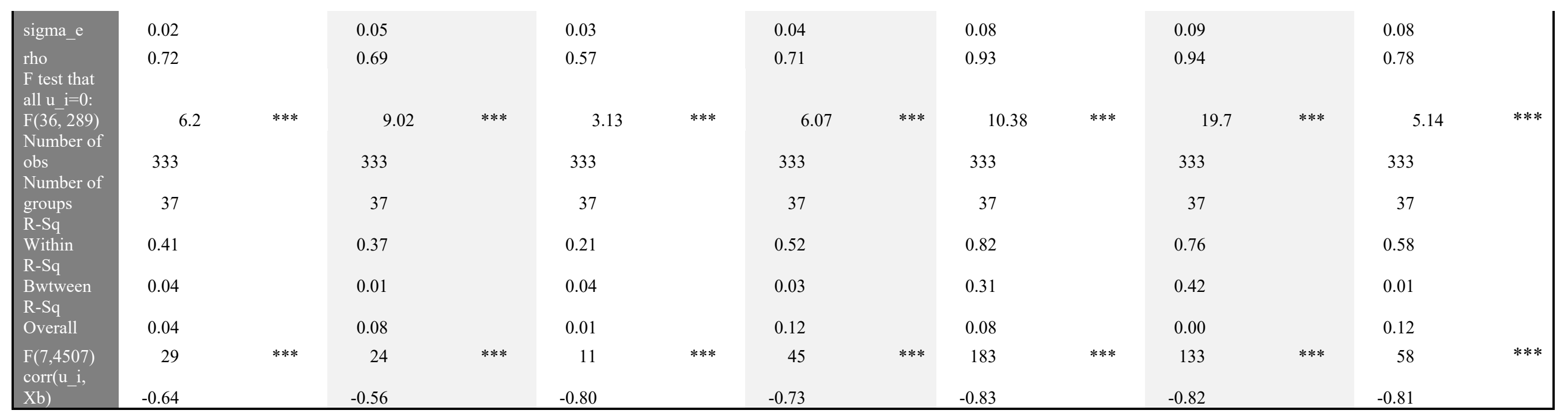

Table F. WFH Effects on Small Business Performa, population-averaged generalized linear panel-data models with the GEE approach

\begin{tabular}{|c|c|c|c|c|c|c|c|c|c|c|c|c|c|c|c|c|c|c|c|c|c|}
\hline & \multicolumn{3}{|c|}{ No Cash Flow } & \multicolumn{3}{|c|}{$\begin{array}{c}\text { Cash Flow foe 1-4 } \\
\text { Weeks }\end{array}$} & \multicolumn{3}{|c|}{$\begin{array}{c}\text { Cash Flow for 1-2 } \\
\text { Months }\end{array}$} & \multicolumn{3}{|c|}{$\begin{array}{c}\text { Cash Flow for 3+ } \\
\text { Months }\end{array}$} & \multicolumn{3}{|c|}{$\begin{array}{c}\text { Increase } \\
\text { Operating } \\
\text { Revenue }\end{array}$} & \multicolumn{3}{|c|}{ Temporary Closure } & \multicolumn{3}{|c|}{$\begin{array}{l}\text { Disruption in } \\
\text { Supply Chain }\end{array}$} \\
\hline & \multicolumn{3}{|c|}{ Model (30) } & \multicolumn{3}{|c|}{ Model (31) } & \multicolumn{3}{|c|}{ Model (32) } & \multicolumn{3}{|c|}{ Model (33) } & \multicolumn{3}{|c|}{ Model (34) } & \multicolumn{3}{|c|}{ Model (35) } & \multicolumn{3}{|c|}{ Model (36) } \\
\hline & \multicolumn{2}{|c|}{ St. } & & \multicolumn{3}{|c|}{ St. } & \multicolumn{3}{|c|}{ St. } & \multicolumn{3}{|c|}{ St. } & \multicolumn{3}{|c|}{ St. } & \multicolumn{3}{|c|}{ St. } & Coef. & $\begin{array}{l}\text { St. } \\
\text { Er. }\end{array}$ & \\
\hline \multicolumn{22}{|c|}{ WFH: Work From Home } \\
\hline WFH (t-1) & 0.02 & 0.04 & & 0.08 & 0.12 & & 0.01 & 0.07 & & 0.22 & 0.08 & $* *$ & 0.50 & 0.22 & $* *$ & -0.39 & 0.26 & & -0.36 & 0.20 & $*$ \\
\hline \multicolumn{22}{|c|}{ Time Effects } \\
\hline afterSHO (t-1) & -0.02 & 0.00 & $* * *$ & -0.04 & 0.01 & $* * *$ & 0.02 & 0.01 & $* * *$ & 0.05 & 0.01 & $* * *$ & 0.10 & 0.01 & $* * *$ & -0.10 & 0.02 & $* * *$ & -0.08 & 0.01 & $* * *$ \\
\hline \multicolumn{22}{|c|}{ COVID: COVID-19 Pandemic Severity } \\
\hline $\begin{array}{l}\text { New Case / 1k } \\
(\mathrm{t}-1)\end{array}$ & 0.03 & 0.02 & & 0.11 & 0.07 & & -0.09 & 0.04 & $* *$ & -0.03 & 0.05 & & 0.14 & 0.11 & & -0.26 & 0.12 & $* *$ & 0.14 & 0.10 & \\
\hline Death Rt (t-1) & 0.77 & 0.26 & $* * *$ & 1.56 & 0.89 & * & 0.36 & 0.50 & & -1.89 & 0.62 & $* * *$ & 2.33 & 1.94 & & -2.59 & 2.23 & & 3.91 & 1.53 & $* * *$ \\
\hline
\end{tabular}




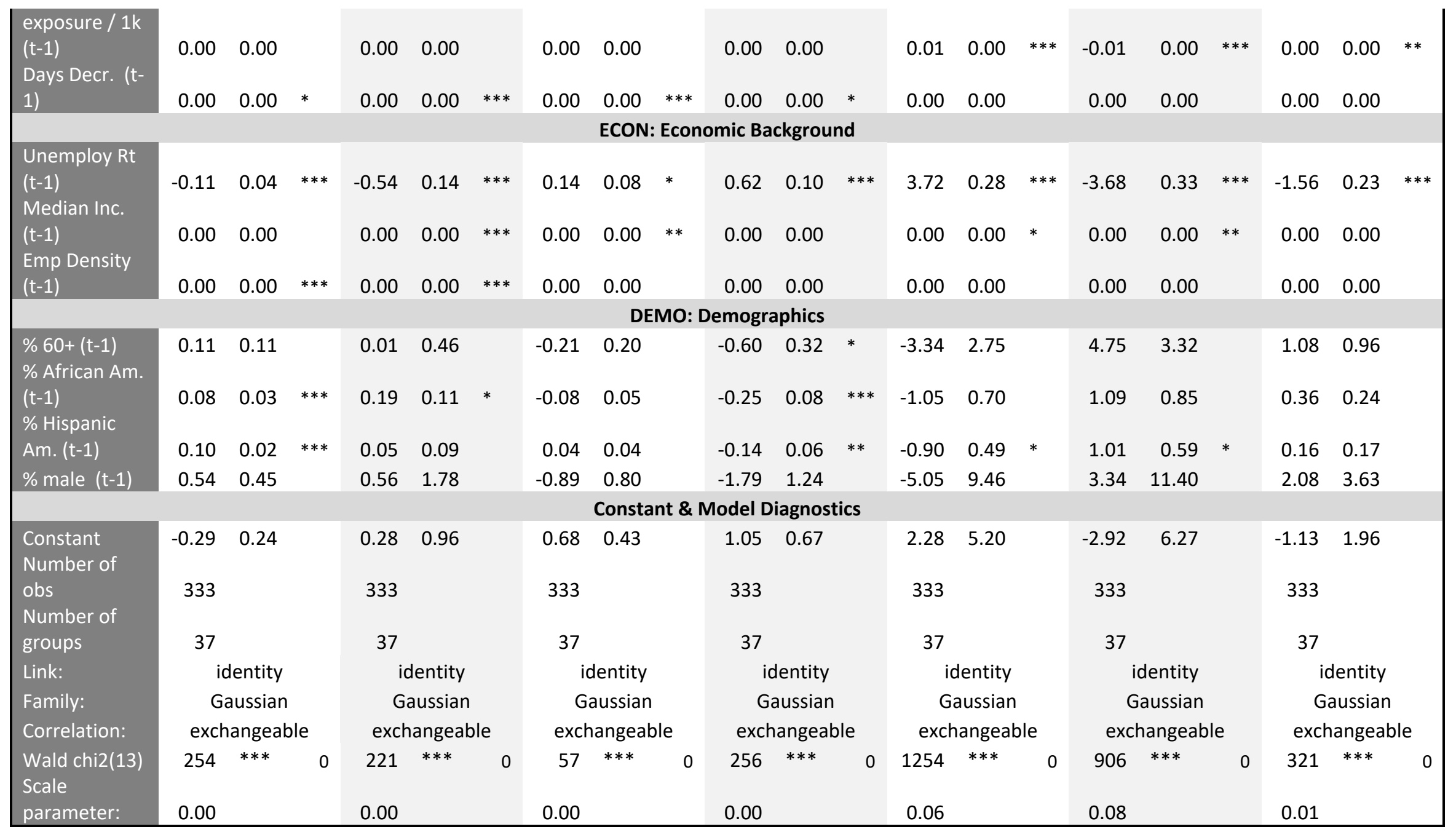


Table G. WFH Effects on Small Business Performa, population-averaged generalized linear panel-data models with the GEE approach, with Industry Sector Fixed Effects

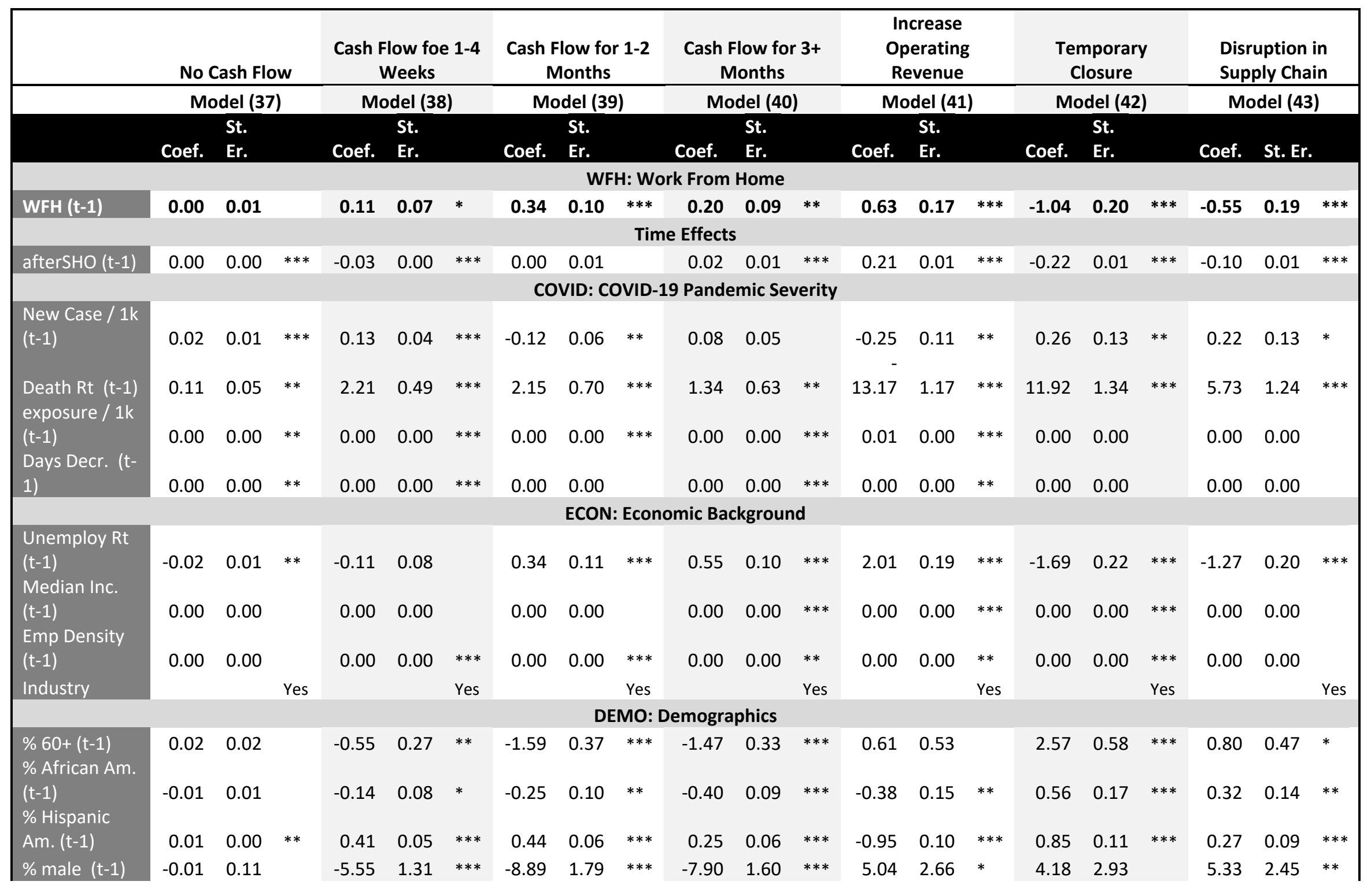




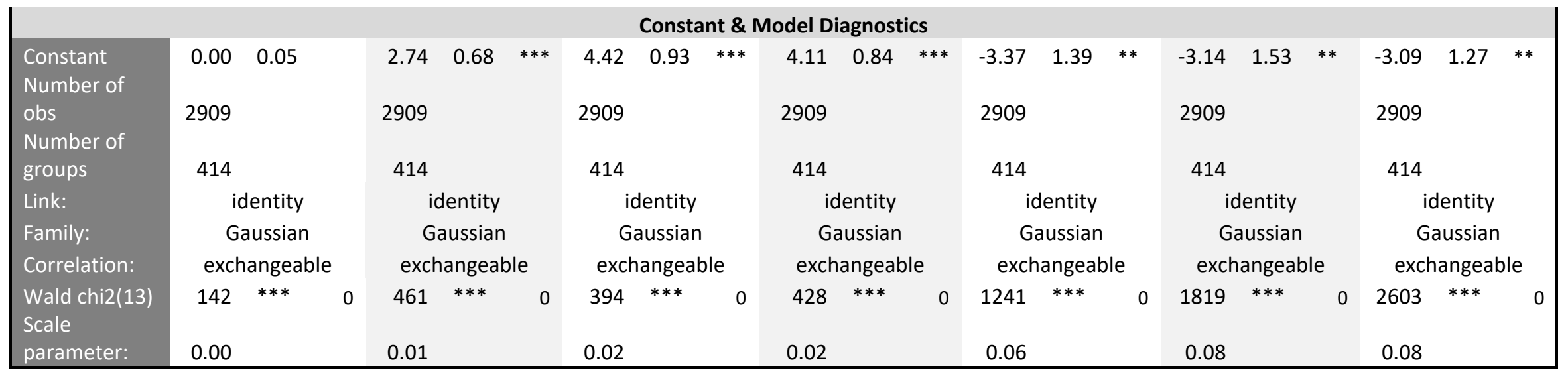


Figures

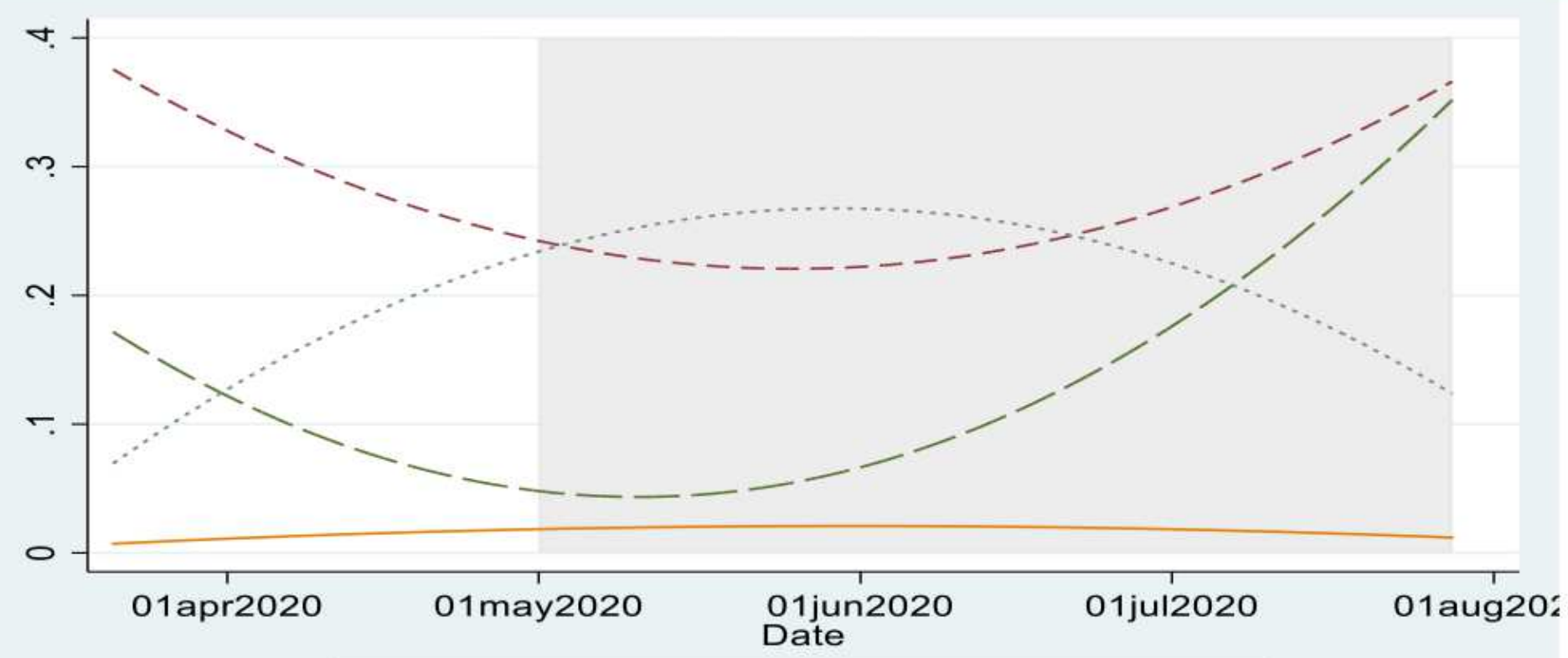

\section{Figure 1}

Trend of WFH, COVID severity, Unemployment, March 21-July 28, 2020

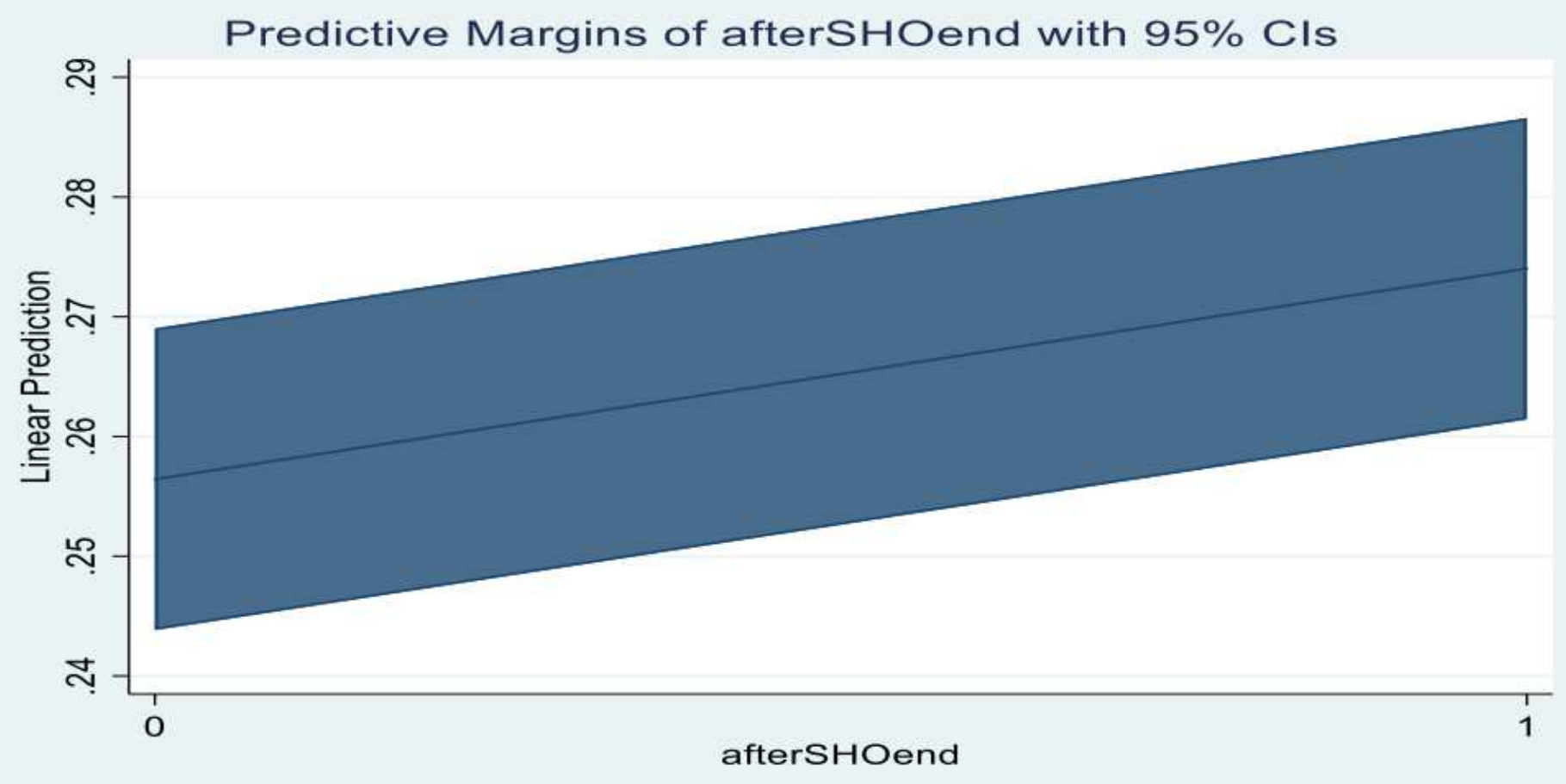


Figure 2

Marginal Effect of the End of SHO on WFH based on Model (4)

No Cash Flow

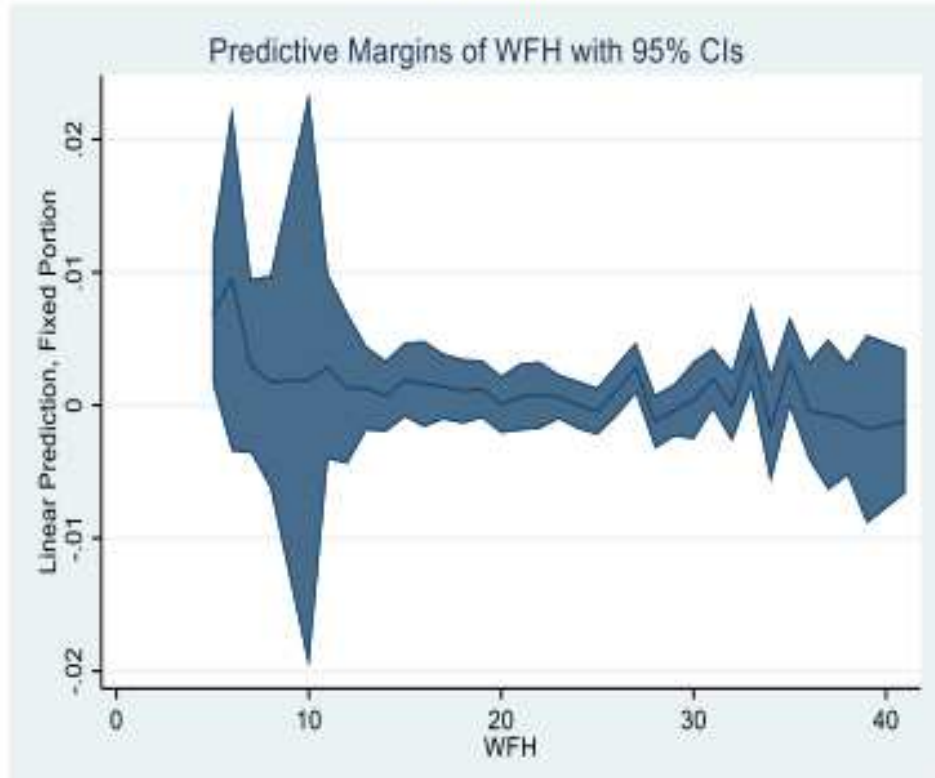

Cash Flow for 1-2 Months

Predictive Margins of WFH with $95 \% \mathrm{Cls}$

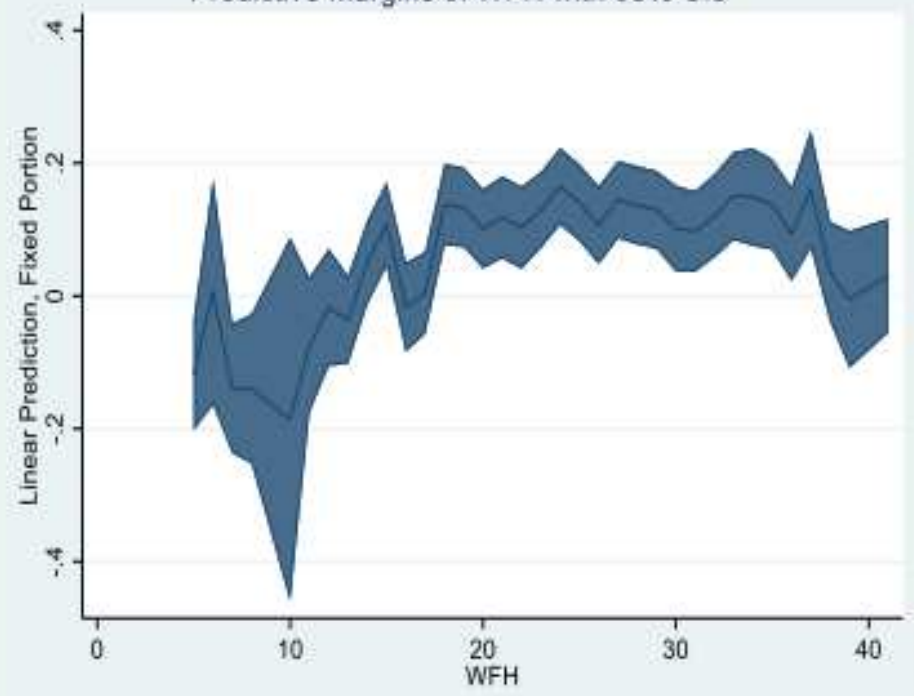

Cash Flow for 1-4 Weeks

Predictive Margins of WFH with $95 \% \mathrm{Cls}$

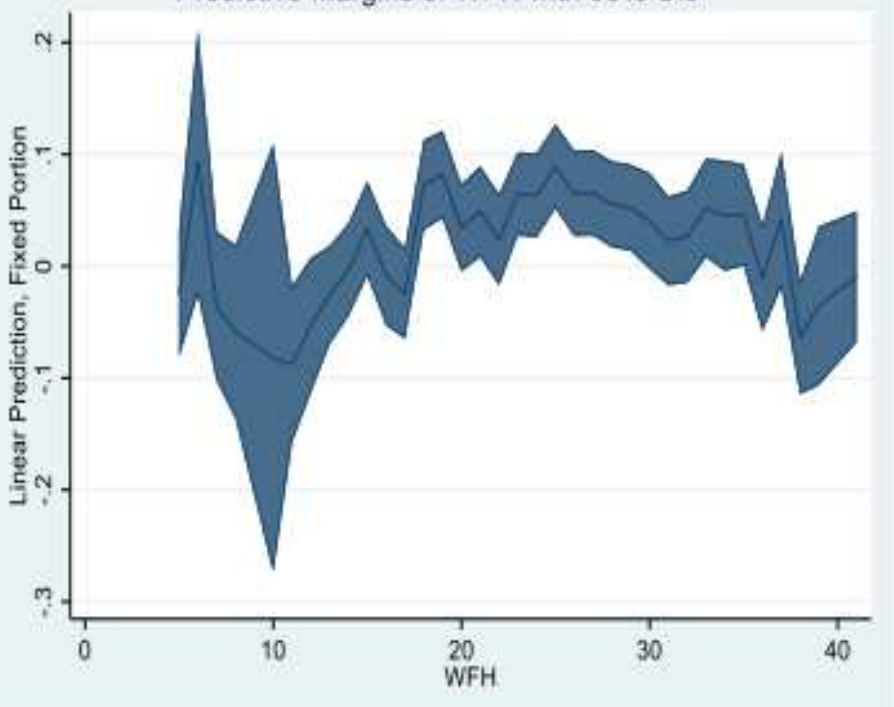

Cash Flow for 1-4 Weeks

Predictive Margins of WFH with $95 \% \mathrm{Cls}$

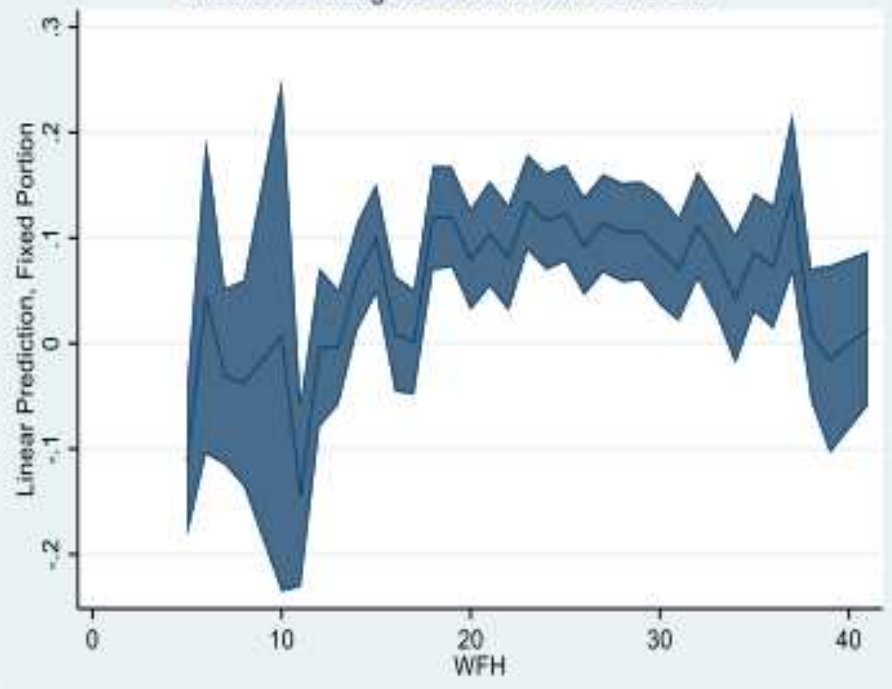

Note: This graph omitted observations for WFH rate below $3 \%$ and above $50 \%$ (i.e., omitting two tails at $2 \%$ and $51-56 \%$ ) because those observation only represent $0.7 \%$ of the observations, but have a much larger and more dramatic effect from WFH rates. Presenting those in the graph will visually inflate the WFH effects.

\section{Figure 3}

WFH Rate Effects on Small Business' Cash Flow, Based on Models (12)-(15) 
For WFH Rate between $3-50 \%$ (99.3\% of observation)

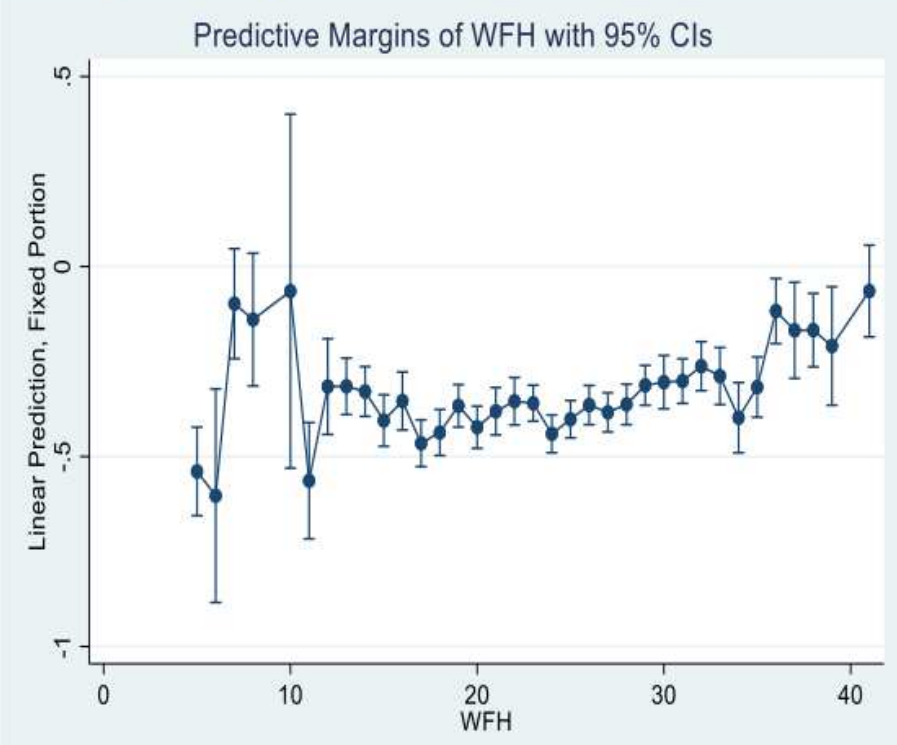

For All WFH Rates (2-56\%)

Predictive Margins of WFH with $95 \% \mathrm{Cls}$

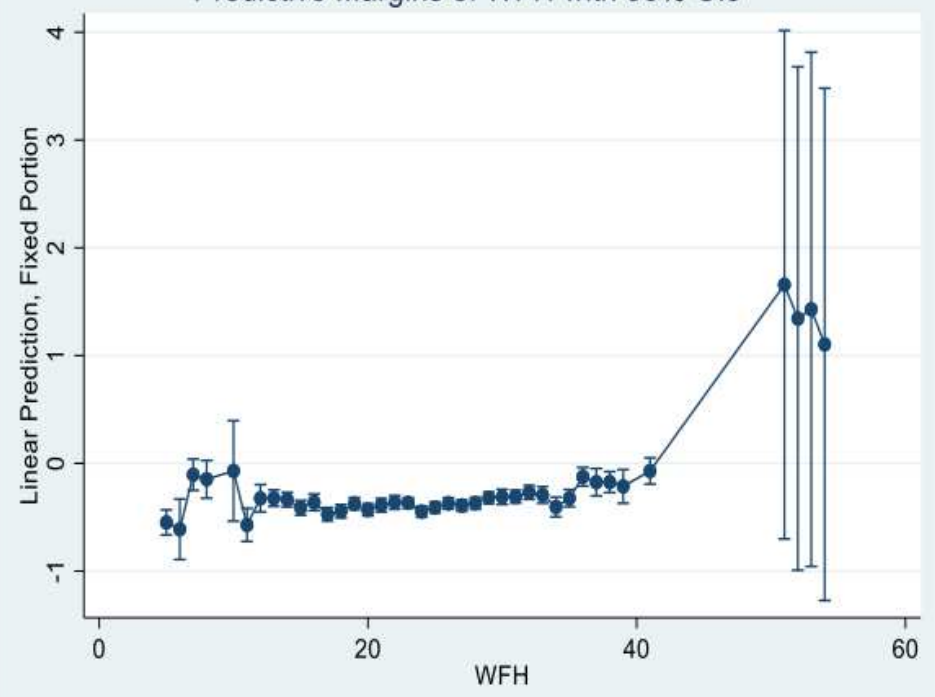

Figure 4

WFH Effects on Small Business' Operating Revenue Increase, Based on Model (16)

For WFH Rate between 3-50\% (99.3\% of observation)

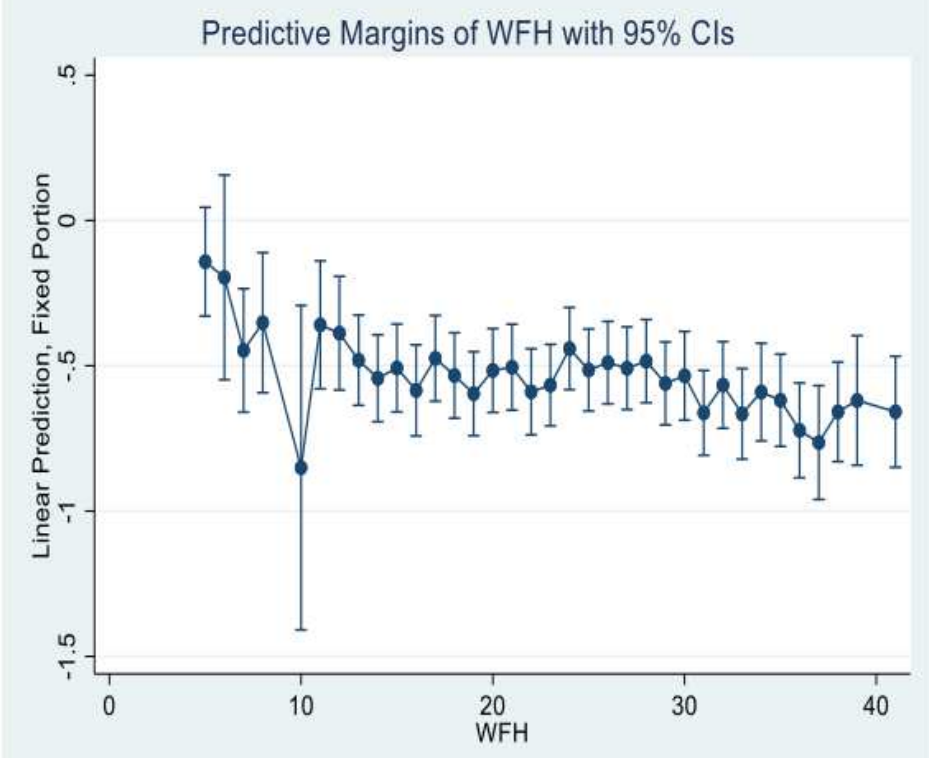

For All WFH Rates (2-56\%)

Predictive Margins of WFH with $95 \% \mathrm{Cls}$

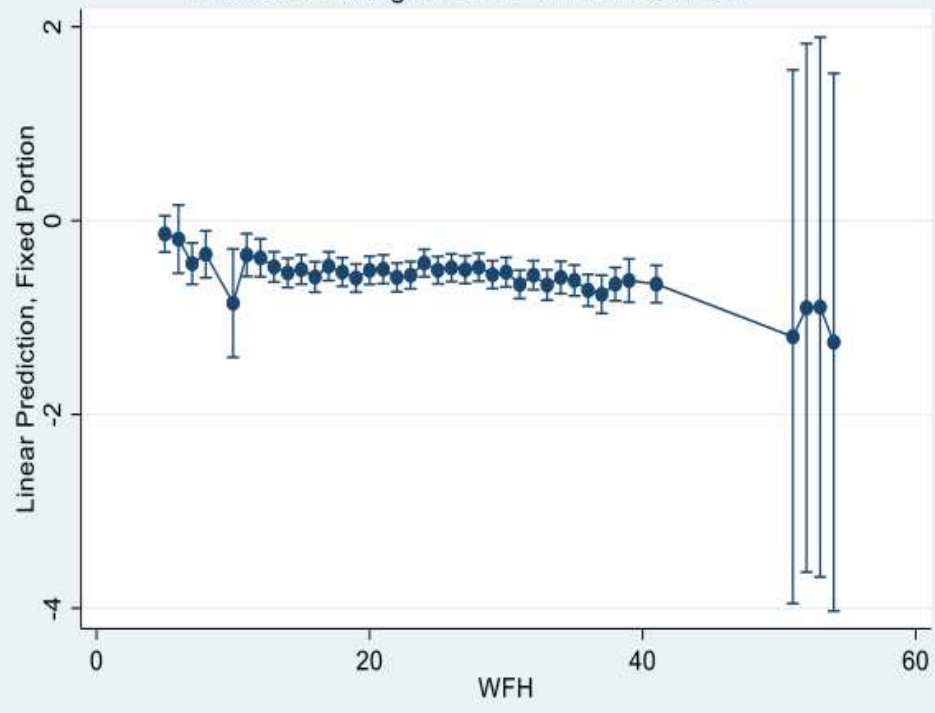

Figure 5

WFH Rate Effects on Small Business' Temporary Closure, Based on Model (17) 
For WFH Rate between 3-50\% (99.3\% of observation)

Predictive Margins of WFH with $95 \%$ Cls

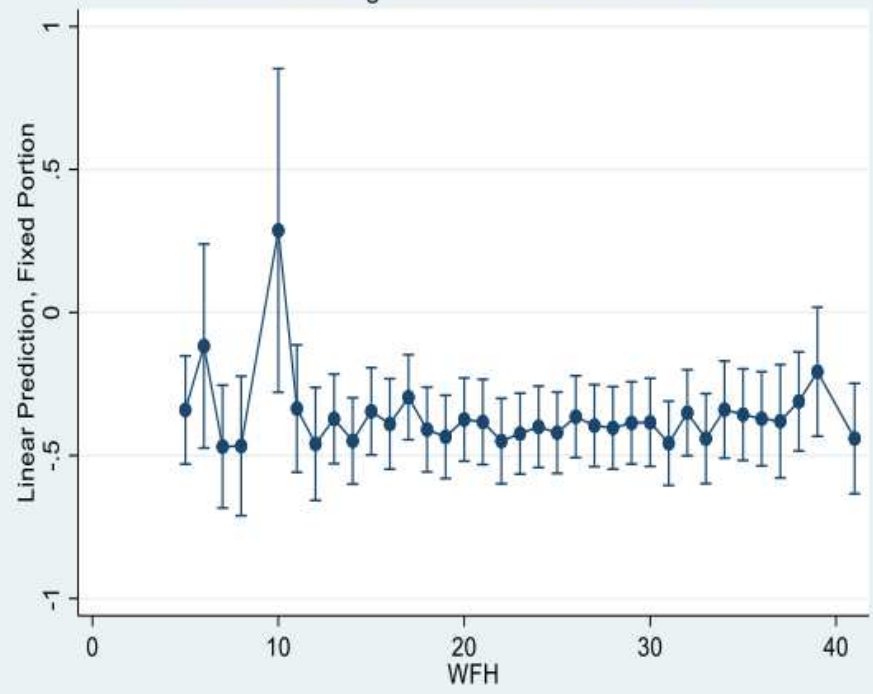

For All WFH Rates (2-56\%)

Predictive Margins of WFH with $95 \% \mathrm{Cls}$

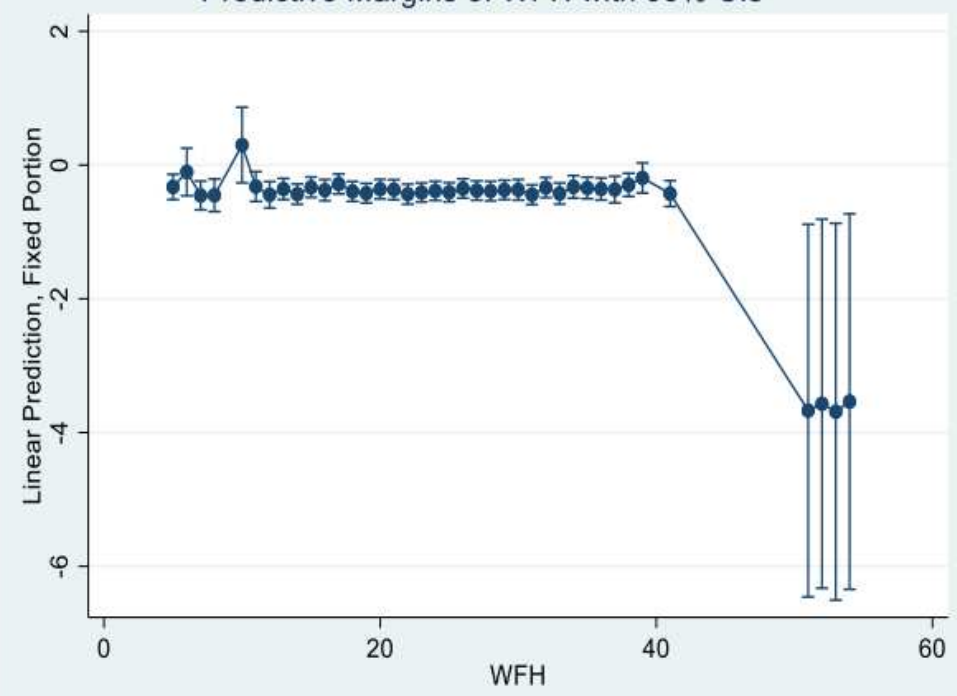

Figure 6

WFH Rate Effects on Small Business' Disruption in Supply Chain, Based on Model (18) 